\title{
State intervention in banking: the relative health of Indian public sector and private sector banks ${ }^{1}$
}

\author{
Viral Acharya (NYU-Stern, NBER and CEPR) \\ Krishnamurthy V. Subramanian (Indian School of Business)
}

The health of Indian public sector banks has come under intense spotlight in recent times. In this chapter, we undertake a critical analysis of public sector banks by comparing them with new private sector banks. Our analysis raises several concerns about the health of Indian public sector banks and thereby the efficacy of the Indian banking system going forward. First, unless Indian public sector banks raise significant capital in the next five years, their balance sheets would have to shrink alarmingly for their capital to remain over the levels mandated by Basel 3 requirements. Second, Indian public sector banks pose significantly greater systemic risk to the Indian banking system when compared to private sector banks. Third, the higher vulnerability of public sector banks stems from the combination of: (i) significant distress combined with thin capital; (ii) asset growth and high leverage, which is funded with volatile wholesale liabilities; (iii) depleting human capital; and, (iv) challenges in adapting to the technological changes engendered by mobile banking technologies.

\footnotetext{
${ }^{1}$ Acharya is grateful to Michael Robles of VLAB for help with NYU Stern Systemic Risk Rankings calculations for Indian financial firms. Krishnamurthy Subramanian would like to thank Venkatesh Ramamoorthy for excellent research assistance.
} 


\section{Introduction}

The blow-up of United Bank of India and the subsequent resignation by its chairman, which is unprecedented in the history of public sector banks (PSBs), has turned the spotlight on the health of PSBs. Though the distress of the PSBs has aggravated significantly over the last couple of years, the inherent competitiveness of PSBs has been a cause for concern for some time now. Even when the PSBs were relatively healthier in 2008, the Rajan committee report had opined "those who argue that PSBs are in good health simply do not understand that they are condemning them to oblivion. Indeed, it seems to me that there are interest groups that want PSBs to remain the way they are only because they can continue to be a cash cow, to be milked dry" (The Economic Times, 26th Fed 2014, page 16). The key question that arises therefore in the context of the Indian banking sector is whether state intervention in banking has worked.

To study this question, in this chapter, we undertake a critical analysis of PSBs. As part of this exercise, we use private sector banks - especially the new private sector banks - to serve as a useful benchmark for comparison. To focus attention on the perilous state of Indian PSBs, we provide evidence based on a wide-ranging set of data that examine (1) the capital position of public sector banks vis-à-vis private sector banks, especially given the upcoming adoption of Basel 3 capital standards; (2) the systemic risk posed by public sector banks vis-à-vis private sector banks; and, (3) their relative profitability.

We then discuss the likely causes relating to the divergent measures of capital, systemic risk and profitability between public sector banks and private sector banks, focusing on (1) asset growth and funding risk from liabilities; (2) efficiency of operations; (3) quality of human capita; and, (4) adoption of newer technologies. We conclude the chapter with some policy conclusions based on our analysis.

\section{Capital position of public sector banks vis-a-vis private sector banks}

Transition arrangements to meet the capital adequacy norms stipulated by Basel 3 have been kick-started by the Reserve bank of India. Therefore, it is important to understand the current capital position of PSBs vis-a-vis the regulatory mandated levels. Table 1 shows the capital adequacy position of the public sector and private sector banks as on March 2014. As Table 2 shows, as at end-March 2014, RBI required a minimum tier-I capital as a proportion of risk assets of at least 6.5 per cent and requires a higher 7.0 per cent as at end-March 2015. As seen in column 1 of Table 1, as of March 2014, all public sector banks were in compliance with the tier-I capital requirements. However, the capital position for public sector banks is likely to be overstated because of the regulatory forbearance which RBI provides on restructured assets. Without forbearance these assets would be categorised as non-performing assets (NPAs), the restructuring being a response to likely imminent default. As a consequence, provisioning would rise and tier-I capital would fall. To examine the tier 1 capital ratios if the regulatory forbearance were not provided, we follow the methodology adopted by the P J Nayak committee on governance of bank boards and examine the impaired capital ratios under three different scenarios. These scenarios are as follows: 
Scenario 1: No regulatory forbearance on restructured assets is available and a 70 per cent provision cover is required. This is an extremely prudent scenario.

Scenario 2: Regulatory forbearance is available in terms of RBI's present norms for restructured assets, together with the need to maintain a 70 per cent provision cover. Further, a 4.25 per cent provision cover is maintained for restructured assets. We also project in this scenario that $30 \%$ of outstanding restructured assets would convert each year into NPAs. This scenario is less prudent than Scenario 1.

Scenario 3: Regulatory forbearance is available as before, and the provision cover is lowered to 50 per cent. As in Scenario 2, a 4.25 per cent provision cover is maintained for restructured assets and $30 \%$ of restructured assets are projected to be converted into NPAs. This is a weaker discipline imposed on banks.

As Table 1 shows, in scenario 1, the tier 1 capital ratios of all public sector banks would be significantly lower than the regulatory mandated levels of $6.5 \%$ with 4 public sector banks (Andhra bank, Central bank of India, Punjab and Sind bank, United bank of India) becoming insolvent. In the less prudent scenario 2, 70\% (=15 of the 21) of the public sector banks would have tier 1 capital ratios that are lower than the regulatory mandated levels of $6.5 \%$. Even in the least prudent scenario 3, about $40 \%$ (=8 of the 21 ) of the public sector banks would have tier 1 capital ratios that are lower than the regulatory mandated levels of $6.5 \%$. In contrast, all the private sector banks would have tier 1 capital ratios that are significantly higher than the regulatory mandated levels $6.5 \%$ even in the most prudent scenario 1. 
Table 1: Capital position of public sector and private sector banks

\begin{tabular}{|c|c|c|c|c|}
\hline Bank Name & Tier-I CAR & $\begin{array}{c}\text { Impaired } \\
\text { Tier-1 CAR } \\
\text { (Scenario 1) }\end{array}$ & $\begin{array}{c}\text { Impaired } \\
\text { Tier-1 CAR } \\
\text { (Scenario 2) }\end{array}$ & $\begin{array}{c}\text { Impaired } \\
\text { Tier-1 CAR } \\
\text { (Scenario 3) }\end{array}$ \\
\hline \multicolumn{5}{|l|}{ Public sector banks } \\
\hline STATE BANK OF INDIA & 9.72 & 4.09 & 7.36 & 9.10 \\
\hline ALLAHABAD BANK & 7.51 & 0.32 & 4.31 & 5.86 \\
\hline ANDHRA BANK & 8.09 & $(0.10)$ & 4.49 & 6.18 \\
\hline BANK OF BARODA & 9.28 & 4.72 & 7.87 & 8.90 \\
\hline BANK OF INDIA & 7.24 & 3.79 & 5.70 & 6.52 \\
\hline BANK OF MAHARASHTRA & 7.44 & 3.54 & 6.35 & 7.30 \\
\hline CANARA BANK & 7.68 & 2.46 & 5.63 & 6.44 \\
\hline CENTRAL BANK OF INDIA & 7.37 & (3.15) & 2.73 & 4.57 \\
\hline CORPORATION BANK & 8.14 & 0.90 & 5.02 & 6.32 \\
\hline DENA BANK & 7.43 & 2.09 & 5.54 & 6.54 \\
\hline IDBI BANK LIMITED & 7.79 & 4.05 & 6.40 & 7.36 \\
\hline INDIAN BANK & 10.24 & 4.59 & 7.87 & 8.97 \\
\hline INDIAN OVERSEAS BANK & 7.47 & 1.86 & 4.87 & 6.10 \\
\hline ORIENTAL BANK OF COMMERCE & 8.86 & 0.10 & 5.25 & 6.66 \\
\hline PUNJAB AND SIND BANK & 7.62 & $(0.29)$ & 4.20 & 5.56 \\
\hline PUNJAB NATIONAL BANK & 8.87 & 2.00 & 6.16 & 7.64 \\
\hline SYNDICATE BANK & 8.68 & 3.08 & 6.83 & 8.00 \\
\hline UCO BANK & 8.71 & 2.71 & 6.87 & 8.44 \\
\hline UNION BANK OF INDIA & 7.54 & 2.66 & 5.55 & 6.71 \\
\hline UNITED BANK OF INDIA & 6.54 & $(1.46)$ & 2.16 & 4.39 \\
\hline VIJAYA BANK & 8.12 & 4.14 & 6.69 & 7.57 \\
\hline \multicolumn{5}{|l|}{ Private sector banks } \\
\hline AXIS BANK & 12.62 & 12.60 & 13.86 & 14.22 \\
\hline DCB BANK LIMITED & 12.86 & 14.21 & 14.55 & 14.55 \\
\hline HDFC BANK & 11.77 & 14.01 & 14.07 & 14.07 \\
\hline ICICI BANK & 12.78 & 12.75 & 13.83 & 14.34 \\
\hline INDUSIND BANK & 12.71 & 14.58 & 14.69 & 14.69 \\
\hline KOTAK MAHINDRA BANK LTD. & 17.77 & 19.48 & 19.56 & 19.88 \\
\hline YES BANK LTD. & 9.80 & 12.00 & 12.03 & 12.03 \\
\hline
\end{tabular}


Table 2: Basel 3 capital requirements - transitional arrangements for Indian banks

\begin{tabular}{|c|c|c|c|c|c|c|}
\hline Minimum capital ratios & $\begin{array}{l}\text { 31-Mar- } \\
14\end{array}$ & $\begin{array}{l}\text { 31-Mar- } \\
15\end{array}$ & $\begin{array}{l}\text { 31-Mar- } \\
16\end{array}$ & 31-Mar-17 & 31-Mar-18 & 31-Mar-19 \\
\hline $\begin{array}{l}\text { Minimum Common Equity } \\
\text { Tier } 1 \text { (CET1) }\end{array}$ & $5.000 \%$ & $5.500 \%$ & $5.500 \%$ & $5.500 \%$ & $5.500 \%$ & $5.500 \%$ \\
\hline $\begin{array}{l}\text { Capital conservation buffer } \\
\text { (CCB) }\end{array}$ & - & - & $0.625 \%$ & $1.250 \%$ & $1.875 \%$ & $2.500 \%$ \\
\hline Minimum $\mathrm{CET} 1+\mathrm{CCB}$ & $5.000 \%$ & $5.500 \%$ & $6.125 \%$ & $6.750 \%$ & $7.375 \%$ & $8.000 \%$ \\
\hline $\begin{array}{l}\text { Minimum Tier } 1 \text { capital (Min. } \\
\text { CET1+Additional Tier } 1 \text { ) }\end{array}$ & $6.500 \%$ & $7.000 \%$ & $7.000 \%$ & $7.000 \%$ & $7.000 \%$ & $7.000 \%$ \\
\hline $\begin{array}{l}\text { Minimum Total Capital (Tier } \\
1+\text { Tier } 2 \text { ) }\end{array}$ & $9.000 \%$ & $9.000 \%$ & $9.000 \%$ & $9.000 \%$ & $9.000 \%$ & $9.000 \%$ \\
\hline Minimum Total Capital + CCB & $9.000 \%$ & $9.000 \%$ & $9.625 \%$ & $10.250 \%$ & $10.875 \%$ & $11.500 \%$ \\
\hline
\end{tabular}

Figure 1 below shows that on an average, over the past 6 years, new private banks have 3.5 percentage points more tier 1 capital than PSBs.

Figure 1: Average tier 1 capital ratios for public and new private sector banks

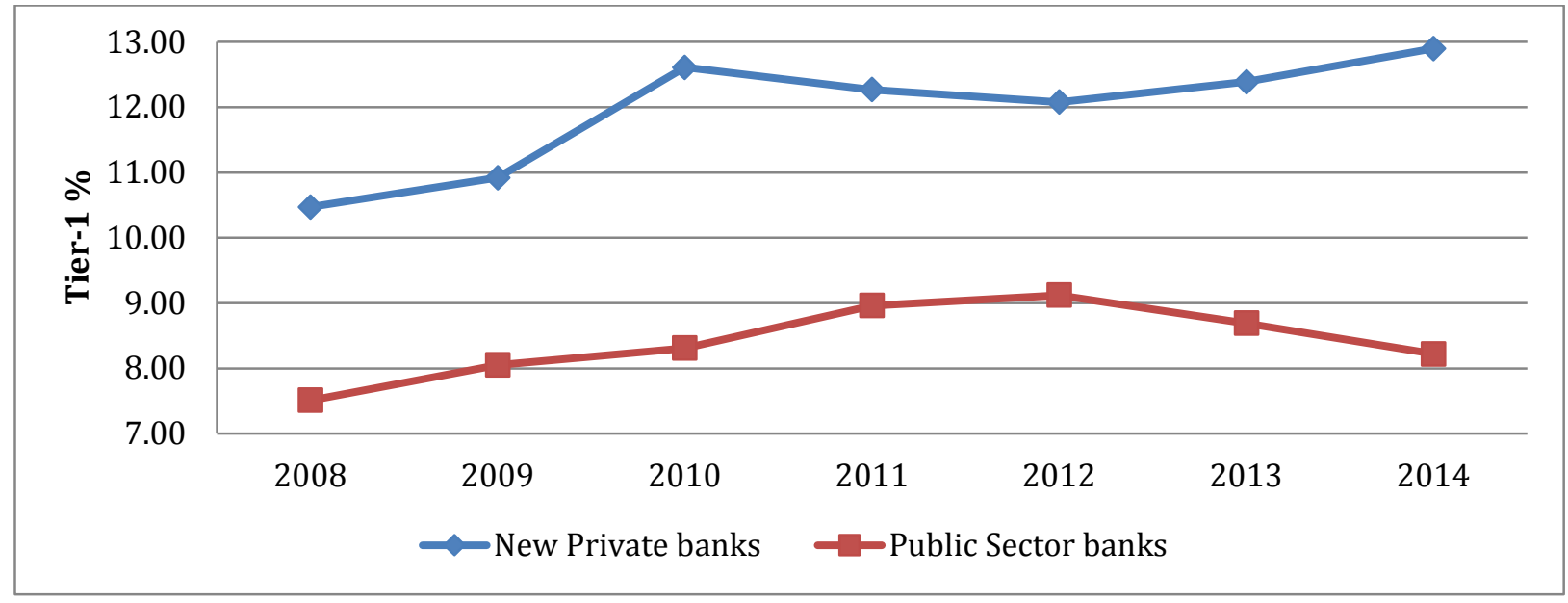

As Table 2 shows, the capital requirements mandated by Basel 3 ramp up significantly in the forthcoming years with the minimum total capital plus the capital conservation buffer increasing from 9\% as of March 2014 to $11.5 \%$ by March 2019. As we saw in Table 1, devoid of the cushion provided by regulatory forbearance, a significant number of public sector banks are already weakly capitalised. Therefore, given the significant increase in regulatory capital requirements in the forthcoming years, it is quite useful to estimate the expected capital requirements for both PSBs and new private banks in the forthcoming years.

We estimate the capital requirements from Mar-14 to Mar-19. For this purpose, we assume that the risk weighted assets of banks to grow at a nominal growth rate of 16 per cent. Given the recent deterioration in the quality of assets, we assume that the ratio of gross NPAs to risk weighted assets, the ratio of restructured assets to risk weighted assets, and the ratio of provisions to risk weighted assets in the period up to March 2019 would equal 
their averages over the one year ended March 2014. These growth rates are computed separately for PSBs and new private banks to reflect their distinct rate of growth. We also assume that the return on equity and the payout ratios would equal their historical averages estimated over the last five and three years respectively. Further, we assume that 30 per cent of outstanding restructured assets would convert into NPAs every year. Finally, we provide for a 4.25 per cent for FY 2014-15, and a 5 per cent cover for restructured assets thereafter. As seen in Table 3, the total capital required by public sector banks equals Rs. 9,97,400 crores under the extremely prudent Scenario 1, Rs. 6,53,300 crores under the less prudent Scenario 2, and Rs. 5,12,300 crores under the least prudent Scenario 3. These amounts translate into 2.6, 1.7 and 1.3 times the aggregate market capitalisations of public sector banks as of 7 May 2015.

Table 3: Capital shortfall estimates of public sector banks

\begin{tabular}{|c|c|c|c|c|c|c|}
\hline & \multicolumn{3}{|c|}{ Capital shortfall ('000 crores) } & \multicolumn{3}{|c|}{$\begin{array}{c}\text { Capital shortfall as a multiple of } \\
\text { total equity market capitalization } \\
\text { (as of 7-May-2015) }\end{array}$} \\
\hline & Scenario 1 & Scenario 2 & Scenario 3 & Scenario 1 & Scenario 2 & Scenario 3 \\
\hline Allahabad & 28.3 & 18.4 & 14.4 & 5.0 & 3.3 & 2.5 \\
\hline Andhra & 17.5 & 10.8 & 8.0 & 4.1 & 2.5 & 1.9 \\
\hline BoB & 57.3 & 32.9 & 22.9 & 1.7 & 1.0 & 0.7 \\
\hline Bol & 83.4 & 57.4 & 46.8 & 6.2 & 4.3 & 3.5 \\
\hline BoMH & 21.8 & 15.5 & 13.0 & 5.7 & 4.1 & 3.4 \\
\hline Canara & 78.0 & 53.7 & 43.8 & 4.6 & 3.2 & 2.6 \\
\hline CBol & 45.7 & 32.3 & 26.8 & 2.5 & 1.8 & 1.5 \\
\hline Corporation & 21.3 & 13.5 & 10.3 & 4.6 & 2.9 & 2.2 \\
\hline Dena & 18.2 & 12.1 & 9.7 & 6.7 & 4.5 & 3.6 \\
\hline IDBI & 63.2 & 44.1 & 36.3 & 5.8 & 4.0 & 3.3 \\
\hline Indian & 20.9 & 12.4 & 8.9 & 3.0 & 1.8 & 1.3 \\
\hline IOB & 47.2 & 33.6 & 28.0 & 9.3 & 6.6 & 5.5 \\
\hline $\mathrm{OBC}$ & 28.8 & 19.3 & 15.4 & 5.1 & 3.4 & 2.7 \\
\hline Punjab \& Sind & 13.5 & 9.4 & 7.7 & 7.1 & 4.9 & 4.0 \\
\hline PNB & 59.9 & 34.4 & 24.0 & 2.1 & 1.2 & 0.8 \\
\hline SBI & 264.2 & 166.8 & 126.9 & 1.3 & 0.8 & 0.6 \\
\hline Syndicate & 23.4 & 14.8 & 11.3 & 3.6 & 2.3 & 1.7 \\
\hline UCO & 22.2 & 14.1 & 10.8 & 3.5 & 2.2 & 1.7 \\
\hline Union & 47.0 & 31.6 & 25.3 & 5.6 & 3.8 & 3.0 \\
\hline United & 21.5 & 16.4 & 14.3 & 9.3 & 7.1 & 6.2 \\
\hline Vijaya & 14.2 & 9.6 & 7.7 & 3.7 & 2.5 & 2.0 \\
\hline Total & 997.4 & 653.3 & 512.3 & 2.6 & 1.7 & 1.3 \\
\hline Min & 13.5 & 9.4 & 7.7 & 1.3 & 0.8 & 0.6 \\
\hline Max & 264.2 & 166.8 & 126.9 & 9.3 & 7.1 & 6.2 \\
\hline Average & 47.5 & 31.1 & 24.4 & 4.8 & 3.2 & 2.6 \\
\hline
\end{tabular}


A similar exercise conducted for the new private sector banks reveals that capital required equals Rs. 9,540 crores under Scenario 1, Rs. 4,980 crores under Scenario 2, and Rs. 1,350 crores under Scenario 3 (see Table 4). Clearly, the new private sector banks are much more comfortably capitalised, and the variance between the three scenarios is very low. Moreover, only 2 banks among the 7 require capital infusion while others do not require to raise capital for their capital adequacy.

Table 4: Capital shortfall estimates of private sector banks

\begin{tabular}{|c|c|c|c|c|c|c|}
\hline & \multicolumn{3}{|c|}{ Capital shortfall ('000 crores) } & \multicolumn{3}{|c|}{$\begin{array}{l}\text { Capital shortfall as a multiple of } \\
\text { total equity market capitalization } \\
\text { (as of 7-May-2015) }\end{array}$} \\
\hline & Scenario 1 & Scenario 2 & Scenario 3 & Scenario 1 & Scenario 2 & Scenario 3 \\
\hline Axis bank & 0.0 & 0.0 & 0.0 & 0.0 & 0.0 & 0.0 \\
\hline DCB bank & 0.5 & 0.4 & 0.4 & 0.1 & 0.1 & 0.1 \\
\hline HDFC bank & 0.0 & 0.0 & 0.0 & 0.0 & 0.0 & 0.0 \\
\hline $\mathrm{IClCl}$ bank & 9.0 & 4.6 & 1.0 & 0.1 & 0.0 & 0.0 \\
\hline Indusind bank & 0.0 & 0.0 & 0.0 & 0.0 & 0.0 & 0.0 \\
\hline Kotak Mahindra bank & 0.0 & 0.0 & 0.0 & 0.0 & 0.0 & 0.0 \\
\hline Yes bank & 0.0 & 0.0 & 0.0 & 0.0 & 0.0 & 0.0 \\
\hline Total & 9.5 & 5.0 & 1.3 & 0.0 & 0.0 & 0.0 \\
\hline Min & 0.0 & 0.0 & 0.0 & 0.0 & 0.0 & 0.0 \\
\hline Max & 9.0 & 4.6 & 1.0 & 0.1 & 0.1 & 0.1 \\
\hline Average & 1.4 & 0.7 & 0.2 & 0.0 & 0.0 & 0.0 \\
\hline
\end{tabular}

In the light of the above scenario, the Government of India has explicitly stated that it would not be able to provide significant amounts to recapitalize the public sector banks. ${ }^{2}$ During post-budget interview in March 2015, the Secretary of Department of Financial Services in the Ministry of Finance stated that the Government cannot afford to invest in the equity of banks whose value is getting eroded and the amount of capital infused will be strictly rationed and subject to performance of banks. Also, the Government on its part won't take the dividends from banks which can be further utilized for internal capital infusion. So, the Government will decide the quantum of capital taking into account the dividends retained by the banks as it happened last year. In the next financial year 2015-16, it plans to infuse Rs. 7,940 crore while Rs. 8,000 crore dividend will be retained by the banks.

Also, the Government is open to stake sale by PSBs, provided they retain 52 per cent ownership of PSBs. We use this scenario to observe how much capital will be raised by PSBs in case they went for stake sale with a threshold of 52 per cent. Table 5 below shows that the proceeds from the stake of PSBs may fetch only Rs. 42,000 crores.

\footnotetext{
${ }^{2}$ http://www.livemint.com/Politics/QVSJN8z29MA4SJAYhjyOIO/Hasmukh-Adhia--Dividends-to-govt-will-be-returned-toPSU-ba.html
} 
Table 5: Maximum proceeds from stake sales of public sector banks

\begin{tabular}{|c|c|c|c|c|}
\hline & $\begin{array}{c}\text { Govt stake } \\
\text { (\%) }\end{array}$ & $\begin{array}{l}\text { Mkt Cap } \\
\text { (May 7) in } \\
\text { '000 } \\
\text { crores }\end{array}$ & $\begin{array}{c}\text { Max stake } \\
\text { sale (\%) }\end{array}$ & $\begin{array}{l}\text { Proceeds from stake } \\
\text { sale based on } \mathrm{mkt} \\
\text { cap on May } 7 \text { in ' } 000 \\
\text { crores }\end{array}$ \\
\hline Allahabad bank & 58.9 & 5.7 & 6.9 & 0.4 \\
\hline Andhra bank & 60.1 & 4.3 & 8.1 & 0.3 \\
\hline Bank of Baroda & 56.3 & 34.0 & 4.3 & 1.5 \\
\hline Bank of India & 66.7 & 13.4 & 14.7 & 2.0 \\
\hline Bank of Maharashtra & 85.2 & 3.8 & 33.2 & 1.3 \\
\hline Canara bank & 69.0 & 16.9 & 17.0 & 2.9 \\
\hline Central bank of india & 88.6 & 18.1 & 36.6 & 6.6 \\
\hline Corporation bank & 63.3 & 4.7 & 11.3 & 0.5 \\
\hline Dena bank & 58.0 & 2.7 & 6.0 & 0.2 \\
\hline IDBI & 76.5 & 10.9 & 24.5 & 2.7 \\
\hline Indian bank & 81.5 & 6.9 & 29.5 & 2.0 \\
\hline Indian overseas bank & 73.8 & 5.1 & 21.8 & 1.1 \\
\hline Oriental bank of commerce & 59.1 & 5.7 & 7.1 & 0.4 \\
\hline Punjab national bank & 58.9 & 29.0 & 6.9 & 2.0 \\
\hline Punjab and Sind bank & 81.4 & 1.9 & 29.4 & 0.6 \\
\hline SBI & 58.6 & 197.7 & 6.6 & 13.0 \\
\hline Syndicate bank & 67.4 & 6.5 & 15.4 & 1.0 \\
\hline UCO bank & 77.2 & 6.3 & 25.2 & 1.6 \\
\hline Union bank of india & 60.1 & 8.4 & 8.1 & 0.7 \\
\hline United bank of india & 88.0 & 2.3 & 36.0 & 0.8 \\
\hline \multirow[t]{2}{*}{ Vijaya bank } & 74.1 & 3.8 & 22.1 & 0.8 \\
\hline & & & Total & 42.4 \\
\hline
\end{tabular}

This situation has to be viewed from the background of low valuations of PSBs in the market. Though they are supposed to have a minimum of industry average market valuation (in the form of Market-to-Book ratio) mainly due to their implicit sovereign guarantee, they are trading well below their counterparts in the market. This reflects poorly in their market capitalization which in turn does not help to raise capital from the market. As we can see from Figure 2 below, over the last ten years, the average market-to-book ratio of new private banks has been three times more than that of PSBs indicating their weak market position. 
Figure 2: Market to book ratios of public and new private sector banks

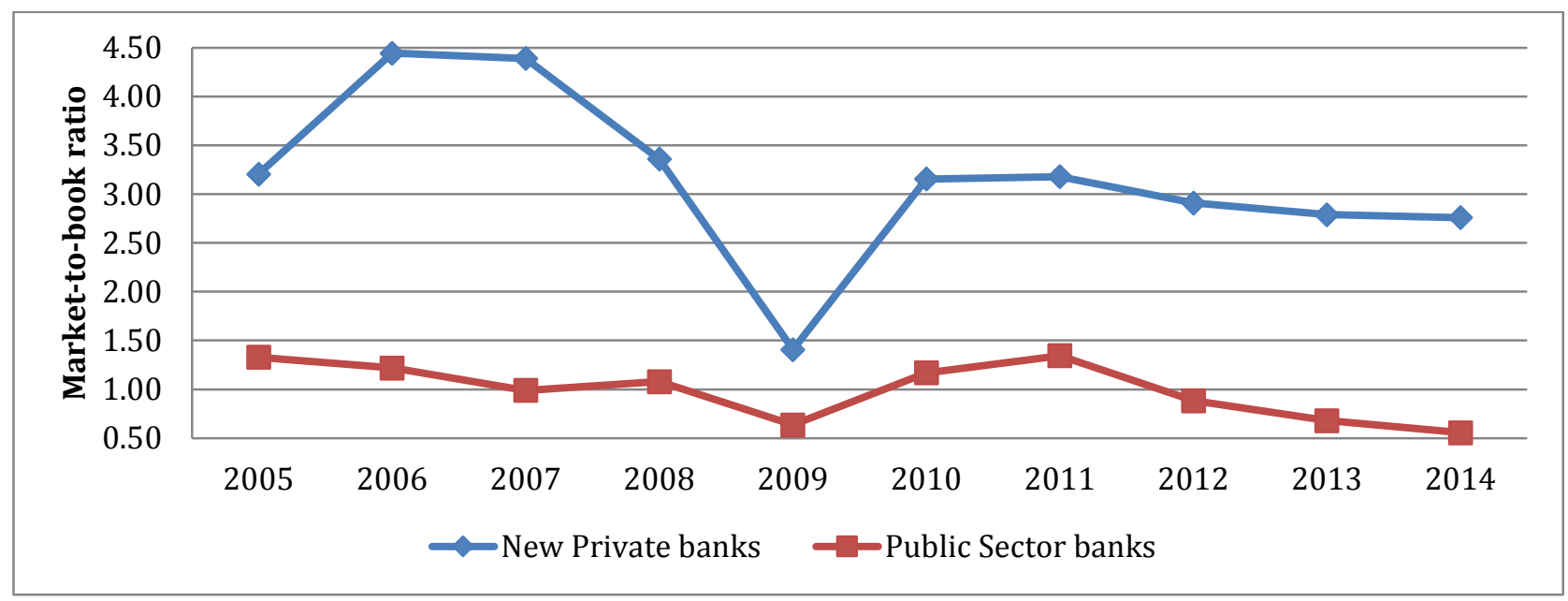

Reflecting the unattractiveness of public sector banks to investors, State Bank of India-the bellwether for PSBs could not raise the intended Rs. 9,600 crore via share sale to institutional investors in January 2014. It could raise only 80 per cent of that amount equating to Rs.8,032 crore; even that 80 per cent transpired only because 41.3 per cent of the issue was bought by the state-owned Life Insurance Corporation of India as foreign investors largely stayed away from the offering. If investors' confidence in the State Bank of India is feeble, then their conference in other PSBs can only be fragile, which raises significant concerns about PSBs' ability to raise capital from the external markets.

Indian banks have over the period of 2009-2014 raised equity of Rs. 61,734 crore, of which Life Insurance Corporation (LIC) has contributed significantly. As of September 2014, the average share of LIC in public sector banks has been 9.60 per cent which is a marginal increase compared to that of 9.07 per cent in September 2013. The share of LIC (Life Insurance Corporation of India) ranges from a maximum of 22.54 per cent in Corporation bank to a minimum of State Bank of Mysore of 1.47 per cent. Thus, we can observe that due to lower valuations of PSBs and the subsequent underpricing, another public sector enterprise namely, the LIC has to bear the investments. Though it may appear to be a case of round-tripping of funds in an imprudent way, it also leads to potential financial stability concerns in the market where a systemically important financial institution (LIC) holds substantial shares of major banks in the market. Table 6 below shows the shareholding of LIC in PSBs and their subsequent increase as of September 2014. 
Table 6: Holding of LIC in PSBs (\%)

\begin{tabular}{l|cc}
\hline Bank name & Sep-13 & Sep-14 \\
\hline Corporation Bank & 24.69 & 22.54 \\
Indian Overseas Bank & 8.91 & 14.23 \\
United Bank & 4.60 & 14.19 \\
SBI & 13.43 & 13.50 \\
Bank of Maharashtra & 7.82 & 13.41 \\
Dena Bank & 5.92 & 13.12 \\
Bank of India & 12.67 & 11.81 \\
Punjab National Bank & 13.15 & 11.78 \\
Bank of Baroda & 12.01 & 10.57 \\
Punjab \& Sind Bank & 4.56 & 10.49 \\
Central Bank & 7.03 & 10.04 \\
Allahabad Bank & 10.76 & 9.94 \\
Union Bank & 10.85 & 8.78 \\
Oriental Bank & 10.61 & 8.22 \\
Syndicate Bank & 11.03 & 8.18 \\
UCO Bank & 10.20 & 7.91 \\
IDBI Bank & 8.63 & 7.00 \\
Andhra Bank & 7.98 & 6.74 \\
Canara Bank & 5.48 & 6.04 \\
Vijaya Bank & 12.09 & 6.00 \\
Indian Bank & 2.42 & 2.60 \\
State Bank of Bikaner & 2.22 & 2.02 \\
State Bank of Mysore & 1.47 & 1.47 \\
\hline
\end{tabular}

Now considering the above, wherein we don't expect capital infusion from Government and PSBs cannot raise capital in the market themselves, we predict a deceleration in their growth. PSBs may have to shrink their balance sheets in order to maintain their capital over the regulatory mandated levels by 2019 as stipulated by Reserve Bank of India. We estimate the growth rate of risk weighted assets of PSBs in a scenario where there won't be any capital infusion. From Table 7 below, we can observe that the majority of PSBs may have to shrink their balance sheet in case of no external assistance in order to meet the minimum tier 1 capital requirements by 2019. 
Table 7: Projected growth rates of risk weighted assets of PSBs without any capital infusion

\begin{tabular}{|l|r|r|r|}
\hline \multicolumn{3}{|c|}{$\begin{array}{r}\text { Projected growth rates of risk-weighted assets } \\
\text { without any capital infusion }\end{array}$} \\
\hline & Scenario 1 & Scenario 2 & Scenario 3 \\
\hline Allahabad & $-2.0 \%$ & $2.0 \%$ & $5.0 \%$ \\
\hline Andhra & $0.0 \%$ & $5.0 \%$ & $7.0 \%$ \\
\hline BoB & $2.0 \%$ & $7.0 \%$ & $9.0 \%$ \\
\hline Bol & $-5.0 \%$ & $-1.0 \%$ & $1.0 \%$ \\
\hline BoMH & $-9.0 \%$ & $-4.0 \%$ & $-2.0 \%$ \\
\hline Canara & $-6.0 \%$ & $-1.0 \%$ & $1.0 \%$ \\
\hline CBol & $-7.5 \%$ & $-3.0 \%$ & $-1.0 \%$ \\
\hline Corporation & $-0.9 \%$ & $3.6 \%$ & $5.9 \%$ \\
\hline Dena & $-3.4 \%$ & $1.0 \%$ & $3.2 \%$ \\
\hline IDBI & $-6.6 \%$ & $-2.3 \%$ & $-0.2 \%$ \\
\hline Indian & $1.4 \%$ & $6.0 \%$ & $8.3 \%$ \\
\hline IOB & $-8.3 \%$ & $-4.2 \%$ & $-2.1 \%$ \\
\hline OBC & $-3.6 \%$ & $0.8 \%$ & $3.0 \%$ \\
\hline Punjab \& Sind & $-6.2 \%$ & $-1.9 \%$ & $0.3 \%$ \\
\hline PNB & $2.2 \%$ & $6.9 \%$ & $9.2 \%$ \\
\hline SBI & $-0.7 \%$ & $3.8 \%$ & $6.1 \%$ \\
\hline Syndicate & $-0.8 \%$ & $3.7 \%$ & $6.0 \%$ \\
\hline UCO & $-1.0 \%$ & $3.5 \%$ & $5.8 \%$ \\
\hline Union & $-3.9 \%$ & $0.5 \%$ & $2.7 \%$ \\
\hline United & $-19.9 \%$ & $-16.3 \%$ & $-14.5 \%$ \\
\hline Vijaya & $-4.4 \%$ & $0.0 \%$ & $2.2 \%$ \\
\hline Min & $-19.9 \%$ & $-16.3 \%$ & $-14.5 \%$ \\
\hline Max & $2.2 \%$ & $7.0 \%$ & $9.2 \%$ \\
\hline Average & $-4.0 \%$ & $0.5 \%$ & $2.7 \%$ \\
\hline
\end{tabular}




\section{Systemic risks faced by Indian public sector banks}

Market-based data can help assess the preparedness of Indian banks to deal with future losses. At NYU Stern V$\underline{L A B}$ (vlab.stern.nyu.edu/welcome/risk), the capital needs of banks in future stress are estimated relative to a prudential requirement once stress losses are written down against bank equity. In particular, the VLAB estimates use market data to assess the downside risk of banks and assess their "gearing" in a stress scenario by comparing their book liabilities to market value of equity after taking account of the downside market risk. The resulting measure of expected capital shortfall of each financial firm is called SRISK and it can be aggregated across financial firms in a country or types of banks to get an estimate of the aggregate or group-wide SRISK, respectively. The Appendix summarizes the exact computation of SRISK as well as its properties as a measure of financial firm vulnerability to stress.

VLAB estimates of aggregate SRISK for the Indian financial sector are shown in Figure 3. The estimates suggest that as of May 2015, in the event of a $-40 \%$ correction to the global market over a six-month period (as seen in the Great Depression and the Great Recession), the Indian banking sector would require about \$55 billion in market value of equity to maintain a $8 \%$ capital ratio (of market equity to market equity plus book-value of nonequity liabilities). As Figure 3 also shows, the estimated SRISK was also around this level in the Fall of 2008 and $1 Q$ of 2009, reaching a peak of over $\$ 90$ billion following the Federal Reserve "taper" announcement in May 2013. Overall, the estimates highlight that the vulnerability of the Indian financial sector to a global downturn has increased since 2008-09, even though it has reduced somewhat since its peak in 2013.

To put this number in perspective, let us benchmark it. The required capital need as of May 2015 would be over $3 \%$ of India's current GDP and over 25\% of the market value of equity of these firms, the numbers in May 2013 being $6 \%$ and $60 \%$, respectively. As another benchmark, the SRISK for China is about $\$ 300$ billion, so $5 \%$ of Chinese GDP, but only about $15 \%$ of the market value of equity of the financial sector.

While a $-40 \%$ correction to the global market is arguably a rather stressed scenario, these numbers suggest that the Indian financial sector's capacity to recapitalize itself in future stress is worth a careful scrutiny. Figure 4 shows how much of the SRISK for India comes from public-sector banks versus private banks. Unsurprisingly, both given their large share of Indian banking as well as poorer quality of assets, most of the Indian SRISK is composed of the capital needs of public sector banks, with close to $\$ 50$ billion of the estimated total of $\$ 55$ billion coming from these banks. Indeed, this has historically been the case too, though the share of private sector banks to overall SRISK rose somewhat during the "taper" episode.

What is somewhat further disturbing is the concentration of this capital need within the public sector banks. 
Table 9 shows that close to $\$ 40$ billion of the estimated capital need as of May 2015 comes from ten large public sector banks. In contrast, the four largest private sector banks (at bottom of Figure 4) have negative SRISK of total of $\$ 45$ billion, i.e., they are substantially capital surplus. Note that if the private sector banks were expected to be able to move in readily to acquire assets, branches and franchises of public sector banks, then it would be reasonable from an economic standpoint to offset the positive SRISK of public sector banks with the negative SRISK of private sector banks. However, as we elaborate throughout this chapter, such capital mobility is a question mark. Hence, the aggregate SRISK numbers for India shown in Figure 3 and Figure 4 only add up the positive SRISK estimates for Indian financial firms.

Figure 3: SRISK for the Indian Financial Sector

Risk Analysis Overview - India Financials Total SRISK (US\$ billion)

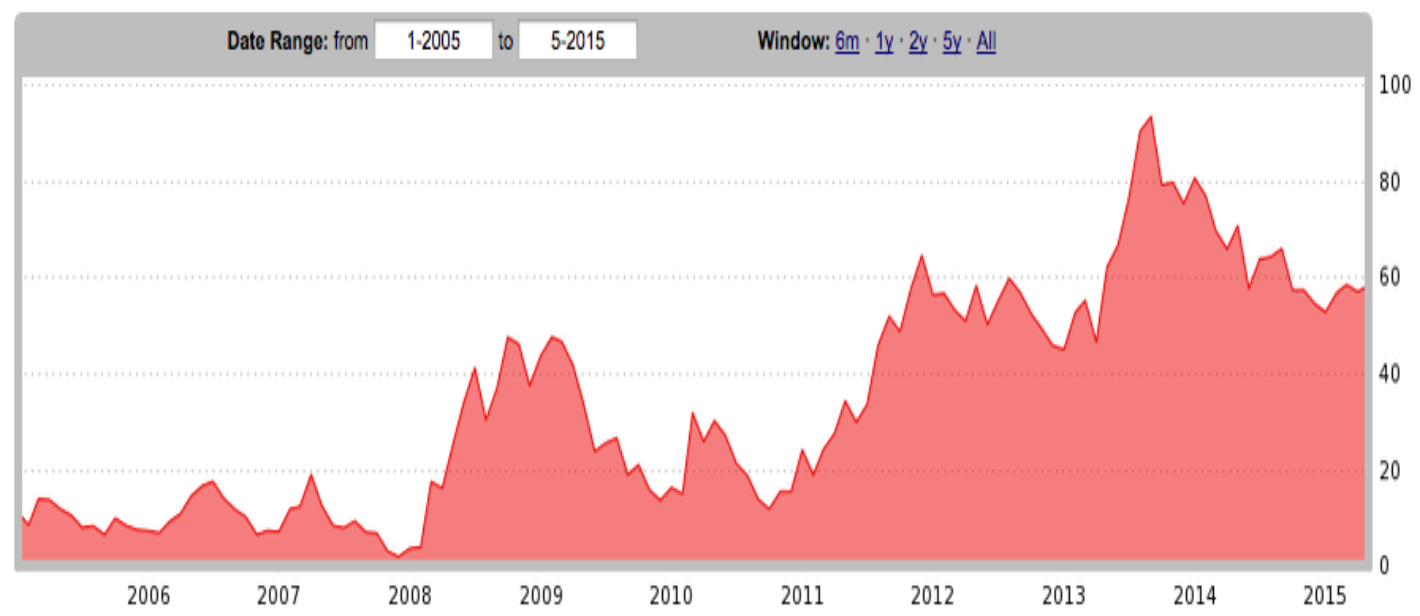

Figure 4: SRISK for the Public Sector and Private Sector Indian Banks

\section{India SRISK (USD million) State-Owned vs Non-State Owned}

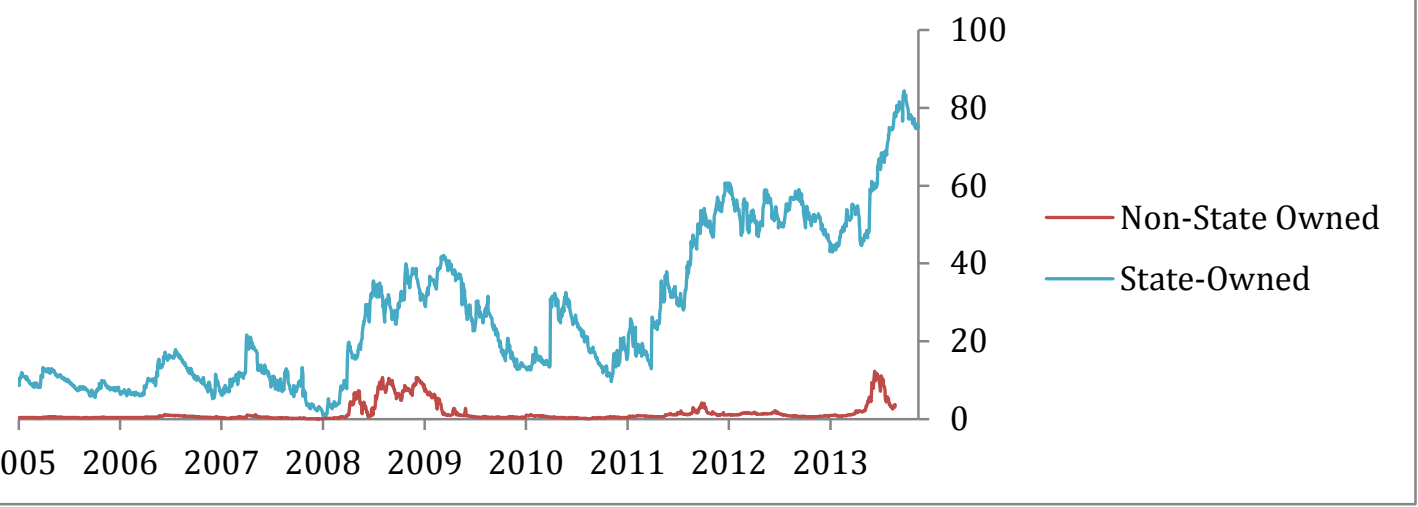


Table 8: SRISK, SRISK ranking (RNK) and SRISK\% (SRISK of a firm divided by total SRISK across positive SRISK firms) using bank by bank estimates for the Indian financial sector (other reported variables are explained in footnote 4 in the Appendix), May 2015

Institution

$\underline{\text { State Bank of India }}$

Bank of India

Bank of Baroda

Canara Bank

Punjab National Bank

Union Bank of India

IDBI Bank Ltd

Indian Overseas Bank

Corp Bank

Syndicate Bank

UCO Bank

Allahabad Bank

Oriental Bank of Commerce

Andhra Bank

Indian Bank

Vijaya Bank

Bank of Maharashtra

Dena Bank

Punjab \& Sind Bank

State Bank of Travancore

State Bank of Bikaner \& Jaipur

State Bank of Mysore

Jammu \& Kashmir Bank Ltd/The

South Indian Bank Ltd/The

Karnataka Bank Ltd/The

Dhanlaxmi Bank Ltd

Lakshmi Vilas Bank Ltd/The

Karur Vysya Bank Ltd/The

Unitech Ltd

IFCI Ltd

DCB Bank Ltd

Federal Bank Ltd

City Union Bank Ltd

Religare Enterprises Ltd

$\begin{array}{cccccccc}\text { SRISK\% } & \text { RNK } & \text { SRISK }(\$ \mathrm{~m}) & \underline{\text { MES }} & \underline{\text { Beta }} & \underline{\text { Cor }} & \underline{\text { Vol }} & \underline{\text { Lvg }} \\ 13.85 & 1 & 8,095 & 2.06 & 0.81 & 0.22 & 32.8 & 12.01 \\ 10.84 & 2 & 6,334 & 2.18 & 0.86 & 0.16 & 52.0 & 47.32 \\ 8.37 & 3 & 4,890 & 2.68 & 1.05 & 0.18 & 43.5 & 18.96 \\ 7.28 & 4 & 4,257 & 2.21 & 0.87 & 0.14 & 40.4 & 27.94 \\ 6.58 & 5 & 3,848 & 1.84 & 0.73 & 0.16 & 35.9 & 20.04 \\ 6.07 & 6 & 3,546 & 1.93 & 0.77 & 0.19 & 38.6 & 34.81 \\ 4.75 & 7 & 2,778 & 2.42 & 0.95 & 0.21 & 45.2 & 27.84 \\ 4.66 & 8 & 2,726 & 1.83 & 0.72 & 0.17 & 34.1 & 50.05 \\ 4.02 & 9 & 2,350 & 1.98 & 0.78 & 0.22 & 36.7 & 48.41 \\ 3.92 & 10 & 2,292 & 2.18 & 0.88 & 0.21 & 40.7 & 32.48 \\ 3.78 & 11 & 2,211 & 2.12 & 0.83 & 0.19 & 47.9 & 34.58 \\ 3.49 & 12 & 2,041 & 2.05 & 0.80 & 0.18 & 38.3 & 35.69 \\ 3.48 & 13 & 2,032 & 2.51 & 0.99 & 0.17 & 43.6 & 33.57 \\ 2.64 & 14 & 1,546 & 1.95 & 0.77 & 0.18 & 37.8 & 34.66 \\ 2.35 & 15 & 1,373 & 1.87 & 0.75 & 0.18 & 33.3 & 22.90 \\ 2.28 & 16 & 1,331 & 1.71 & 0.67 & 0.18 & 31.0 & 36.13 \\ 2.24 & 17 & 1,307 & 2.04 & 0.80 & 0.20 & 35.6 & 34.08 \\ 2.07 & 18 & 1,208 & 1.90 & 0.75 & 0.16 & 33.8 & 44.66 \\ 1.69 & 19 & 988 & 1.74 & 0.66 & 0.16 & 30.3 & 52.03 \\ 1.57 & 20 & 917 & 1.36 & 0.54 & 0.16 & 25.7 & 33.33 \\ 1.13 & 21 & 658 & 1.58 & 0.62 & 0.18 & 30.9 & 23.05 \\ 1.09 & 22 & 637 & 1.68 & 0.66 & 0.21 & 30.9 & 31.90 \\ 0.57 & 23 & 333 & 1.34 & 0.54 & 0.15 & 30.2 & 15.14 \\ 0.51 & 24 & 295 & 1.62 & 0.64 & 0.18 & 30.4 & 16.70 \\ 0.50 & 25 & 293 & 2.07 & 0.82 & 0.17 & 45.9 & 17.70 \\ 0.19 & 26 & 112 & 1.79 & 0.71 & 0.16 & 54.4 & 23.67 \\ 0.09 & 27 & 51 & 1.52 & 0.60 & 0.17 & 31.1 & 12.01 \\ 0.00 & 28 & -45 & 1.16 & 0.46 & 0.11 & 23.5 & 9.69 \\ 0.00 & 29 & -151 & 2.40 & 0.94 & 0.16 & 44.5 & 5.25 \\ 0.00 & 30 & -210 & 2.18 & 0.86 & 0.19 & 42.5 & 5.51 \\ 0.00 & 31 & -213 & 2.24 & 0.87 & 0.24 & 36.3 & 4.17 \\ 0.00 & 32 & -392 & 1.91 & 0.75 & 0.20 & 34.7 & 6.60 \\ 0.00 & 33 & -436 & 1.08 & 0.42 & 0.13 & 32.7 & 4.79 \\ 0.00 & 34 & -476 & 0.96 & 0.38 & 0.15 & 28.4 & 4.07 \\ & 14 & & & & & & \end{array}$




\begin{tabular}{lllllllll} 
Muthoot Finance Ltd & 0.00 & 35 & -553 & 1.64 & 0.65 & 0.09 & 42.5 & 3.88 \\
Reliance Capital Ltd & 0.00 & 36 & -559 & 2.14 & 0.84 & 0.16 & 38.1 & 4.36 \\
L\&T Finance Holdings Ltd & 0.00 & 37 & -676 & 1.72 & 0.70 & 0.23 & 27.0 & 4.50 \\
LIC Housing Finance Ltd & 0.00 & 38 & $-1,020$ & 1.97 & 0.78 & 0.19 & 34.1 & 5.21 \\
Oberoi Realty Ltd & 0.00 & 39 & $-1,028$ & 1.84 & 0.71 & 0.08 & 32.4 & 1.11 \\
Max India Ltd & 0.00 & 40 & $-1,031$ & 1.56 & 0.62 & 0.17 & 42.9 & 3.11 \\
Shriram Transport Finance Co Ltd & 0.00 & 41 & $-1,141$ & 2.58 & 1.00 & 0.13 & 51.1 & 3.36 \\
DLF Ltd & 0.00 & 42 & $-1,316$ & 3.09 & 1.22 & 0.21 & 45.5 & 2.64 \\
Mahindra \& Mahindra Financial & 0.00 & 43 & $-1,362$ & 1.40 & 0.54 & 0.15 & 32.2 & 2.87 \\
Services Ltd & 0.00 & 44 & $-1,557$ & 2.38 & 0.92 & 0.24 & 30.8 & 3.45 \\
IDFC Ltd & 0.00 & 45 & $-1,834$ & 0.83 & 0.33 & 0.12 & 22.0 & 1.03 \\
Bajaj Holdings \& Investment Ltd & 0.00 & 46 & $-1,943$ & 1.31 & 0.52 & 0.10 & 32.8 & 3.70 \\
Bajaj Finserv Ltd & 0.00 & 47 & $-2,130$ & 2.48 & 0.97 & 0.20 & 35.3 & 3.75 \\
Yes Bank Ltd & 0.00 & 48 & $-3,209$ & 2.47 & 1.01 & 0.23 & 33.2 & 2.74 \\
IndusInd Bank Ltd & 0.00 & 49 & $-5,680$ & 3.44 & 1.40 & 0.21 & 39.9 & 4.71 \\
\hline ICICI Bank Ltd & 0.00 & 50 & $-7,138$ & 2.94 & 1.22 & 0.23 & 39.2 & 3.58 \\
Axis Bank Ltd & 0.00 & 51 & $-11,836$ & 1.85 & 0.75 & 0.15 & 35.6 & 1.82 \\
Kotak Mahindra Bank Ltd & 0.00 & 52 & $-17,293$ & 2.37 & 0.94 & 0.31 & 25.5 & 3.16
\end{tabular}

It is also interesting to ask the question how the SRISK of Indian banks has evolved over the past five years and what has contributed to this evolution (changes in liabilities, changes in market values of equity, or changes in downside risk, as explained formally in the Appendix). Table 9 provides such an evolution as well as its decomposition. As the figure shows, barring a few exceptions, the estimated capital needs have risen over the past five years for Indian public sector banks, with the primary contributor to this rise being the increase in debt liabilities that have far outpaced any improvements in market value of equity (with downside risk having also risen in many cases). In contrast, for private sector banks, the estimated capital needs have substantially declined, with any growth in debt liabilities more than offset by the gains in market values of equity (with downside risk having declined in most cases).

Overall, the VLAB estimates of capital needs of Indian banking sector in case of aggregate stress suggest that the Indian public sector banks are substantially under-capitalized relative to private sector banks, and the gap has widened substantially too over the recent past. This is consistent with the other estimates we have shown so far based on calculations for estimated capital needs to meet Basel III norms. The rest of the chapter explores the various reasons that have contributed to this rising gap with the goal of understanding possible remedies. 
Table 9: Changes in SRISK estimates bank by bank for the Indian financial sector (other reported variables are explained in equation (3) in the Appendix), between May 2010 (t-1) and May 2015 (t)

$\underline{\text { Institution }}$

State Bank of India

Bank of India

Bank of Baroda

Canara Bank

Punjab National Bank

Union Bank of India

IDBI Bank Ltd

Indian Overseas Bank

Corp Bank

Syndicate Bank

UCO Bank

Allahabad Bank

Oriental Bank of Commerce

Andhra Bank

Indian Bank

Vijaya Bank

Bank of Maharashtra

Dena Bank

State Bank of Travancore

$\underline{\text { State Bank of Bikaner \& Jaipur }}$

$\underline{\text { State Bank of Mysore }}$

Jammu \& Kashmir Bank Ltd/The

South Indian Bank Ltd/The

Karnataka Bank Ltd/The

Dhanlaxmi Bank Ltd

Lakshmi Vilas Bank Ltd/The

Karur Vysya Bank Ltd/The

Unitech Ltd

IFCI Ltd

DCB Bank Ltd

Federal Bank Ltd

City Union Bank Ltd

Religare Enterprises Ltd

Reliance Capital Ltd

LIC Housing Finance Ltd

8,094.5 2,713.2

6,333.8 2,049.6

$4,889.5$

4,257.5

$3,848.4$

3,546.4

2,777.9

2,726.1

2,350.3

2,291.8

$2,211.2$

2,041.2

$2,032.4$

$1,545.9$

$1,372.7$

$1,330.7$

$1,307.4$

$1,207.7$

917.1

658.4

636.6

333.3

295.3

293.1

111.6

50.7

$-44.8$

$-150.6$

$-210.2$

$-212.6$

$-391.8$

$-436.2$

$-475.5$

$-559.3$

$-1,020.2$
1,398.0

2,132.6

$-153.4$

$\triangle$ SRISK

5,381.4

4,284.2

$3,491.5$

$2,124.8$

$4,001.8$

4,047.

$-43.8$

2,821.6

1,521.6

767.7

$1,204.5$

$1,582.6$

1,679.2

$1,794.8$

612.5

416.4

$1,010.3$

$1,030.9$

980.5

665.8

474.1

179.0

877.0

617.4

517.7

530.1

386.4

163.9

138.2

174.5

$-29.7$

53.9

$-53.3$

$1,051.9$

880.1

898.7

1,151.8

430.3

590.2

399.4

128.3

250.2

169.3

157.1

118.6

141.3

$-3.2$

8.5

$-2,245.7$

$-320.8$

$-13.4$

$-64.7$

$-39.0$

$-744.3$

$-2,413.9$

$-701.3$

110.5

$-199.3$

$-327.1$

$-397.2$

268.8

1,854.7

$-319.0$
$\Delta(\mathrm{DEBT}) \quad \Delta$

4,749.9

$\Delta(\mathrm{EQUITY})$

$-14.6$

$\underline{\Delta(\mathrm{RISK})}$

646.1

2,944.3

$1,474.3$

$-134.3$

3,310.4

31.4

725.2

149.7

$1,494.5$

$1,729.2$

2,000.5

$1,178.5$

272.1

2,875.1

158.4

$-6.5$

$-174.6$

$1,080.0$

946.5

212.4

647.1

$-69.2$

$-138.9$

443.4

617.8

430.2

557.2

$-64.7$

$-71.5$

95.1

162.4

$-45.2$

127.3

6.7

$-49.9$

$-0.5$

87.7

$-68.0$

$-208.5$

$2,308.3$
73.9

249.5

$-119.9$

21.1

50.6

165.4

100.1

95.5

93.6

459.5
48.9

$-225.6$

$-524.3$

$-497.4$

225.2

1,639.3

$-827.7$
$-27.6$

$-87.8$

$-11.0$

14.5

20.4

$-13.6$

111.6

$-56.2$

$-198.1$

$-27.4$ $-6.8$

$-11.6$

$-26.1$

10.2

5.8

$-57.6$

$-18.0$

10.0

13.4

$-32.5$

$-93.3$

40.6

$-24.3$

31.8

0.1

$-51.9$

121.8

49.3 


\begin{tabular}{|c|c|c|c|c|c|c|}
\hline Max India Ltd & $-1,031.1$ & -485.0 & -546.2 & 131.3 & -727.6 & 50.2 \\
\hline $\begin{array}{l}\text { Mahindra \& Mahindra Financial } \\
\text { Services Ltd }\end{array}$ & $-1,361.9$ & -560.3 & -801.6 & 220.8 & $-1,021.4$ & -0.9 \\
\hline$\underline{\text { IDFC Ltd }}$ & $-1,557.1$ & $-2,316.2$ & 759.1 & 261.1 & 665.3 & -167.3 \\
\hline Bajaj Holdings \& Investment Ltd & $-1,833.7$ & -858.1 & -975.6 & -1.6 & -621.4 & -352.6 \\
\hline Bajaj Finserv Ltd & $-1,942.7$ & -62.4 & $-1,880.2$ & 177.6 & $-1,820.9$ & -237.0 \\
\hline$\underline{\text { Yes Bank Ltd }}$ & $-2,129.7$ & -601.7 & $-1,528.0$ & 678.3 & $-2,035.7$ & -170.6 \\
\hline IndusInd Bank Ltd & $-3,208.8$ & -586.5 & $-2,622.3$ & 400.4 & $-3,304.4$ & 281.7 \\
\hline$\underline{\text { ICICI Bank Ltd }}$ & $-5,680.3$ & $-5,051.7$ & -628.5 & 726.1 & $-2,429.0$ & $1,074.4$ \\
\hline Axis Bank Ltd & $-7,138.3$ & $-2,984.4$ & $-4,154.0$ & $1,458.4$ & $-5,077.5$ & -534.9 \\
\hline$\underline{\text { Kotak Mahindra Bank Ltd }}$ & $-11,835.7$ & $-2,662.8$ & $-9,172.9$ & 466.7 & $-8,922.1$ & -717.5 \\
\hline HDFC Bank Ltd & $-17,293.1$ & $-7,365.9$ & $-9,927.2$ & 3,399.9 & $-11,187.8$ & $-2,139.4$ \\
\hline
\end{tabular}

\section{Profitability}

Profitability is another parameter which must be studied in order to study the health of an organization. If PSBs are in a bad shape leading to their weak capital position, then their profitability cannot be far behind. However, in order to confirm our judgement, we observe the profitability measures of PSBs vis-à-vis new private banks.

We examine the performance of the banking sector over the last decade by plotting the average return-on-assets for the two categories of banks during the period 2005 to 2014. A couple of inferences stand out when one observes Figure 5 below.

Figure 5: Return on assets of public and new private sector banks

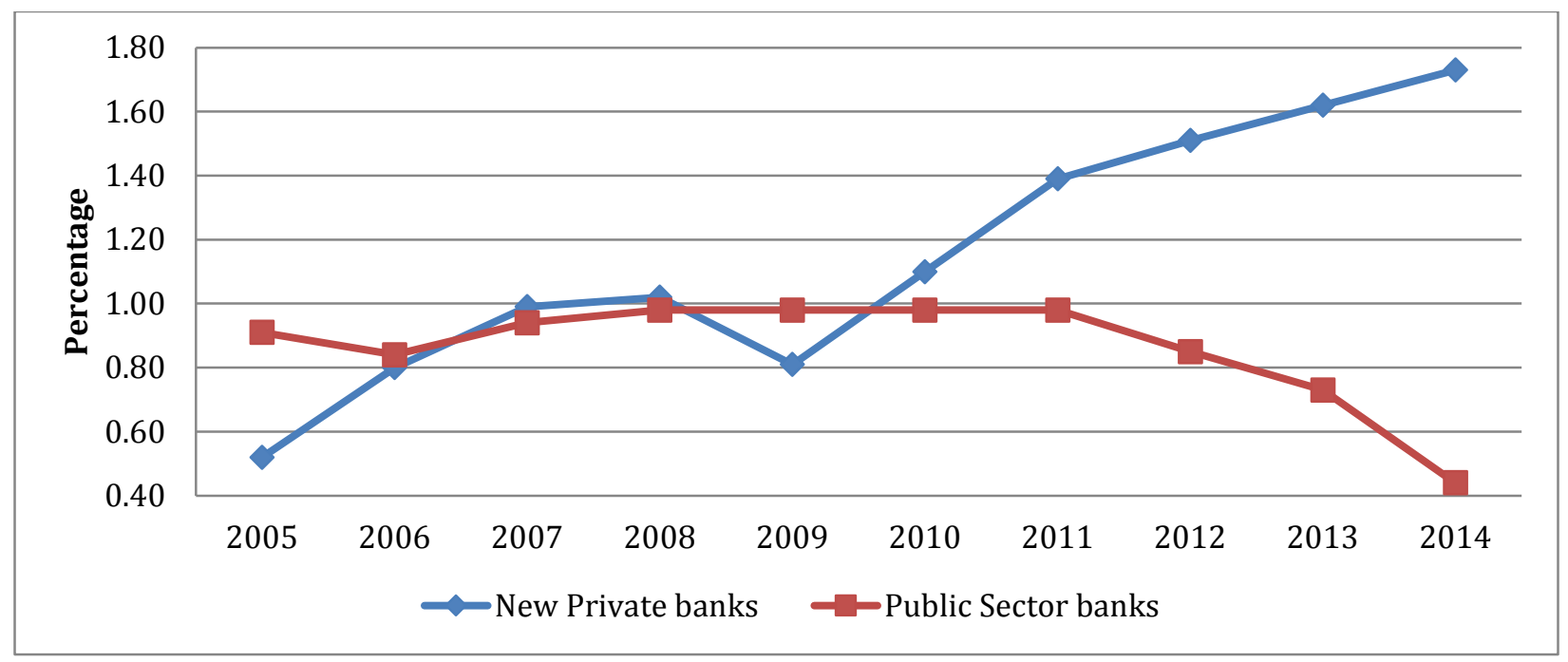

First, since 2007, a scissor-like movement is observed in the return-on-assets of the new private sector banks when compared to the PSBs. In particular, while the return-on-assets for the PSBs other than the State Bank group had remained almost constant at 0.9 per cent from 2008 to 2011, since 2011, the return-on-assets has fallen 
drastically to 0.4 per cent as of FY March 2014. Also, the State Bank groups' return-on-assets has been experiencing decline since 2009. The new private sector banks on the other hand, have managed to maintain a high return-on-assets consistently since 2007 with the exception in 2009 (due to DCB bank). Moreover, the gap between the new private sector banks and the PSBs has been widening since 2007 with the difference being approximately 1.30 percentage points as of March 2014. Moreover, while return-on-assets for old private sector banks has been varying it has been higher than their public sector counterparts since 2008.

Second, there has been a secular decline in the return-on-assets across all bank categories in December 2013 when compared to March 2013. This suggests that the slowing down of the economy is starting to affect the profitability of banks across all categories. In fact the inflection point in the return-on-assets starting in March 2013 suggests that the decline in profitability across all bank categories may continue into the near future. Because the profitability of PSBs is in general low, this declining trend is likely to create significantly more distress in the PSBs than in their private sector counterparts. During the same period, however new private banks register an increase displaying a positive deviation from the macroeconomic conditions.

As our second measure of profitability, we examine the net interest margin for the various categories of banks (see Figure 6). Three inferences are noteworthy in this context. First, we notice that the difference in the net interest margin between the new private sector banks and the other PSBs is significant. Moreover, this difference has been widening since 2008. As of March 2014, the gap in the net interest margin of the new private sector banks vis-à-vis the other PSBs is significant differing by 1 percentage points. Second, while the State Bank group has experienced a decline in the net interest margin since 2011 (from an average of 2.95 per cent to 2.73 per cent in 2014), it has performed better than other PSBs whose average net interest margin has slumped from 2.74 per cent in 2011 to 2.33 per cent in 2014. Third, the net interest margin for the other PSBs has also been falling since March 2011, which again brings into the spotlight the distress in the other PSBs. 
Figure 6: Net interest margins of public and new private sector banks

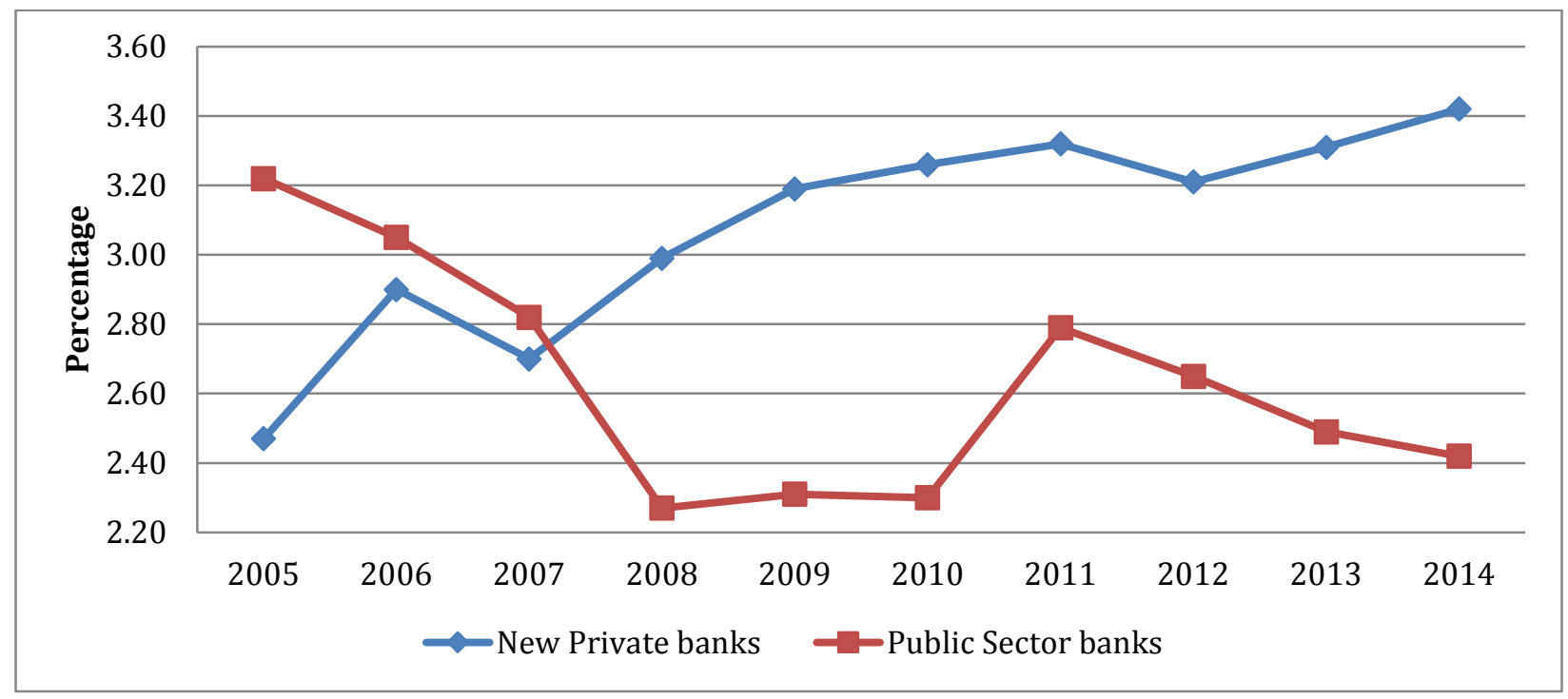

As our third measure of the performance of the Indian banking sector, we examine the market-to-book ratios of banks. We contrast the market-to-book ratios of the PSBs with those of the private sector banks. Here again, we notice that the market-to-book ratios of the private sector banks are substantially greater than that of the PSBs. As of March 2014 while the average market-to-book ratio of the new private sector banks equals 2.76, the average market-to-book ratio of the PSBs equals 0.56 . Since stock market values factor in future profitability as well as current profitability, the significantly lower market-to-book ratios for the PSBs indicates the bleak view of the PSBs in the eyes of the stock market participants. All these measures further buttress the claim that PSBs have been underperforming and are creating less value than private banks. Importantly, the lower market-to-book of these PSBs would also affect detrimentally the PSBs ability to raise capital in the equity markets, accentuated by low probability of Government capital infusion (discussed above in Section 2, Figure 2).

Overall, PSBs low and declining return-on-assets, low and declining net interest margin, low productivity is reflected in the significantly lower market-to-book ratio. Taken together, it is hard to escape the conclusion that PSBs remain a drain on taxpayers' resources apart from being highly susceptible to future shocks.

The majority owner of PSBs, the Government is also not benefitting from them as evident from Figure 7. After being constant at around 18 per cent from 2008 to 2011, the average return on equity has fallen to approx 7 per cent in 2014. At the same time, the private banks have recovered from the fall in 2009 at 10 per cent to a healthy average of 17 per cent in 2014. The major reason for the fall for PSBs are the Nationalised banks whose return on equity has fallen from 18 per cent in 2010 to 6 per cent in 2014 with SBI group faring better at an average of 9.67 per cent in 2014. Thus, PSBs create a dent on the Government's fiscal prudence and deny opportunity for other profitable investment options with its low returns. 
Figure 7: Return on equity of public and new private sector banks

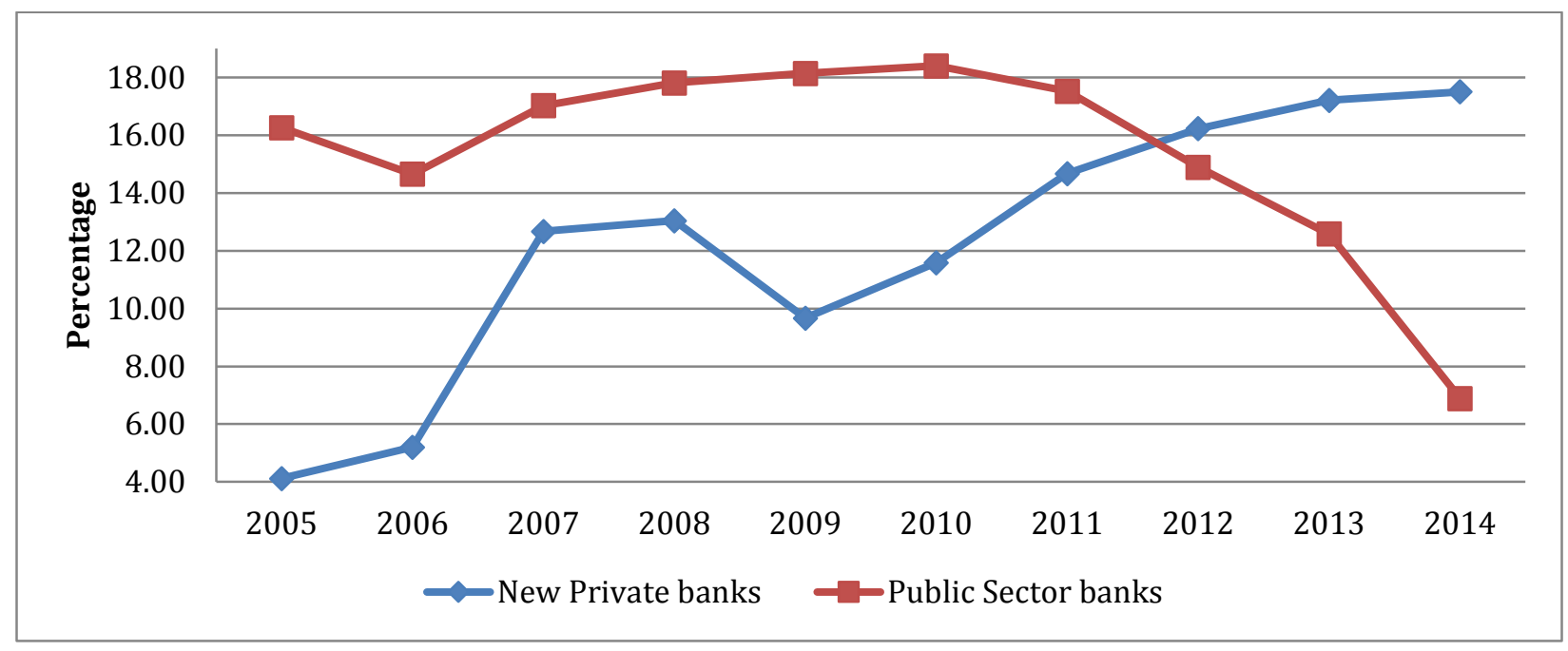

Most of the ills of the PSBs can be singularly traced back to its asset quality, as they are forced to lend at nonoptimal conditions for various non-viable private projects, welfare schemes and also to other public enterprises. Figure 8 and Figure 9 below shows that PSBs and new private banks started off from the same position in 2005 with a declining trend while after the crisis, new private banks have strengthened their credit portfolio and reduced NPAs while PSBs have showed a huge increase in NPAs (Non-Performing Assets). It clearly shows that PSBs have no control over their NPAs in spite of the growing Gross NPA ratio from 2009 to 2014 (from an average of 1.77 per cent to 4.49 per cent). SBI group on the other hand too had not fared well with its Gross NPA ratio soaring from a modest 2.56 per cent in 2009 to 4.96 per cent in 2014. At the same time, the reverse of the above is observed in case of new private banks. The same scenario for PSBs and new private banks can be observed in Net NPA ratio also.

Figure 8: Gross NPA ratios of public and new private sector banks

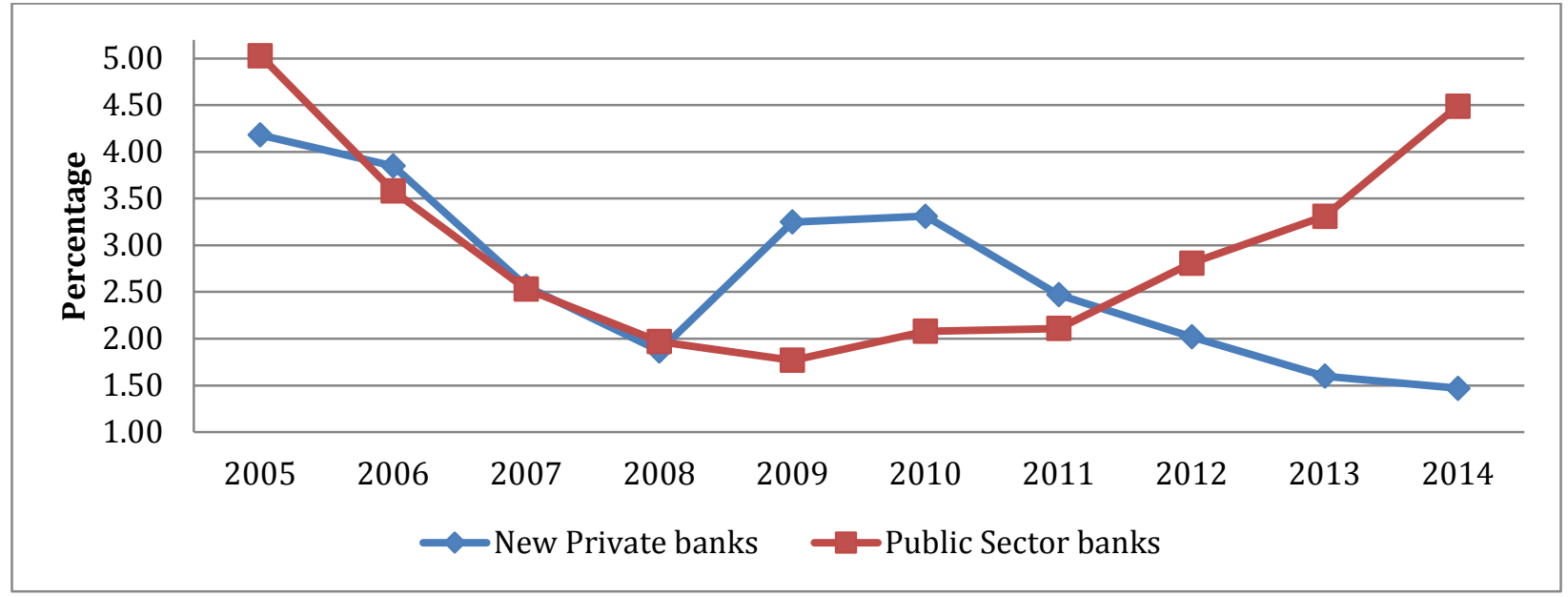


Figure 9: Net NPA ratios of public and new private sector banks

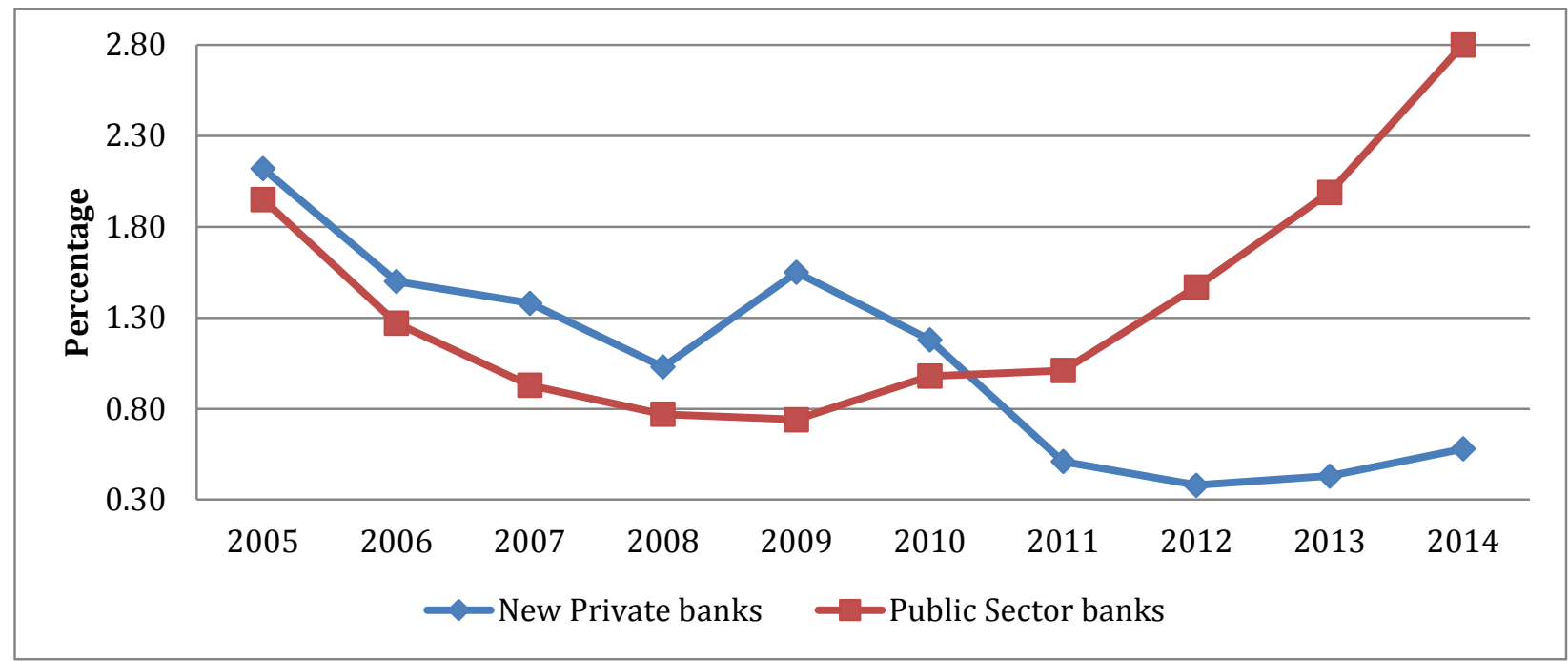

The growth of provisions also corresponds with the growth of NPAs among both the PSBs and new private banks. We can also observe that there is an increasing trend in the Net NPA ratio of new private banks from 2012 indicating an increase in provisions which is evident in Figure 10 also. Thus new private banks are also better equipped to face NPAs in future scenarios given their low NPA ratios.

Figure 10: Level of provisions for stressed assets for public and new private sector banks

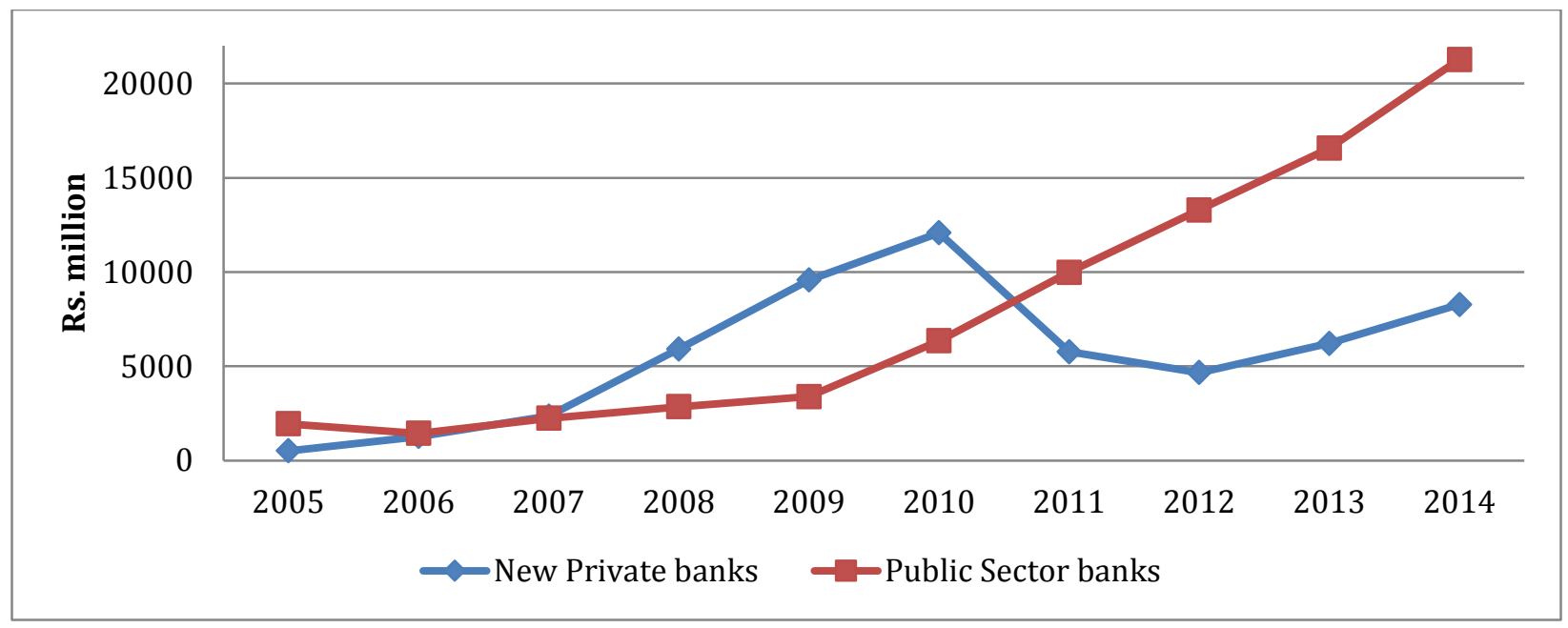

Apart from NPAs, one more important factor that we need to consider to study asset quality is the extent of restructured assets. Restructured assets indicate stress in the credit portfolio which can turn potentially bad in the future. It also camouflages the current asset quality by inter-temporally shifting the credit risk, though it gives a genuine opportunity to mitigate the risk, if done prudently. We can observe that for both PSBs and new private banks the ratio shows an increasing trend indicating an economic slowdown/macroeconomic impact. However, PSBs show much higher proportion of restructured assets than new private banks indicating deteriorating nature 
of their assets posing a huge problem in future. As on March 2014, on average PSBs have accumulated almost 8 times more restructured assets to total assets compared to new private banks (Figure 11).

Figure 11: Ratio of Restructured assets to Gross advances of public and new private sector banks

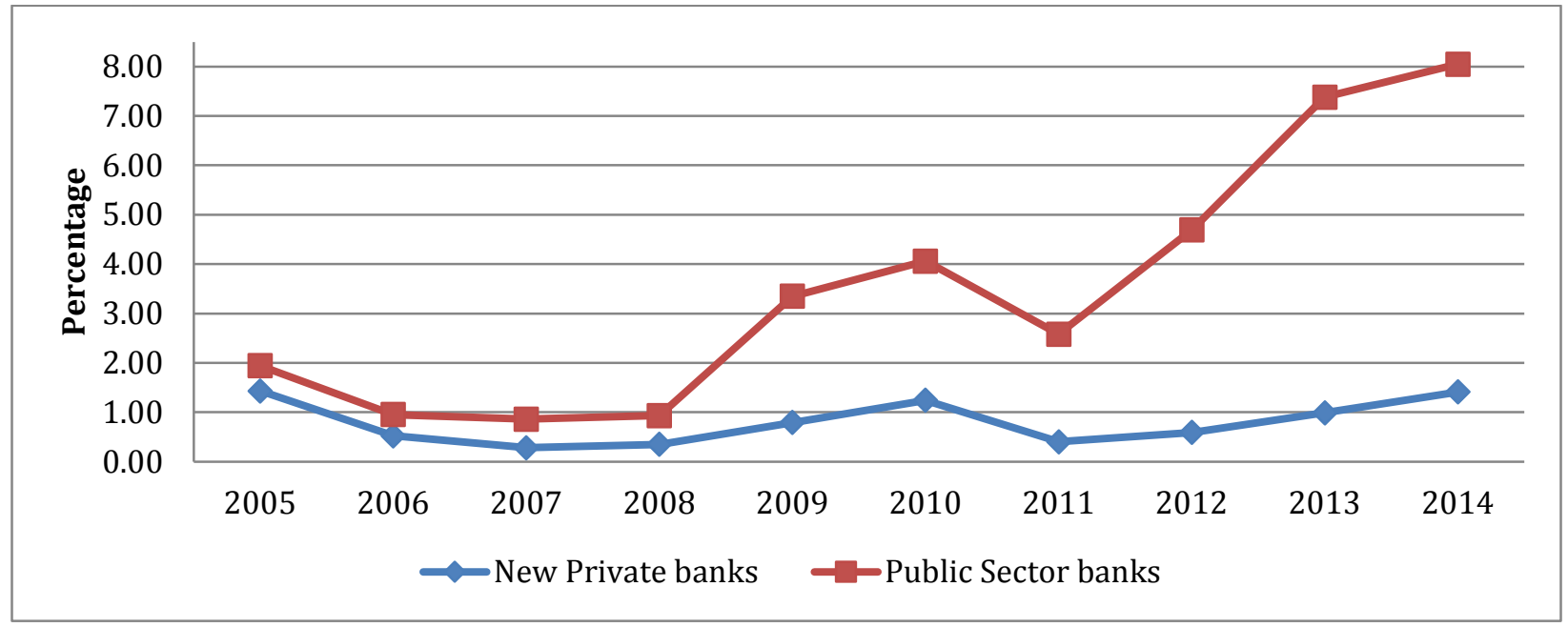

The total stressed assets ratio (combining both NPA and restructured assets) confirms again the issues mentioned above with respect to PSBs and new private banks. Both seems to have undergone same trend (with new private banks significantly lower stressed ratio than PSBs) while PSBs showing a steep spike post 2011 (Figure 12). This again shows that the PSBs have no control over the asset quality posing potential future problems in managing bad assets.

Figure 12: Ratio of stressed assets to Gross advances of public and new private sector banks

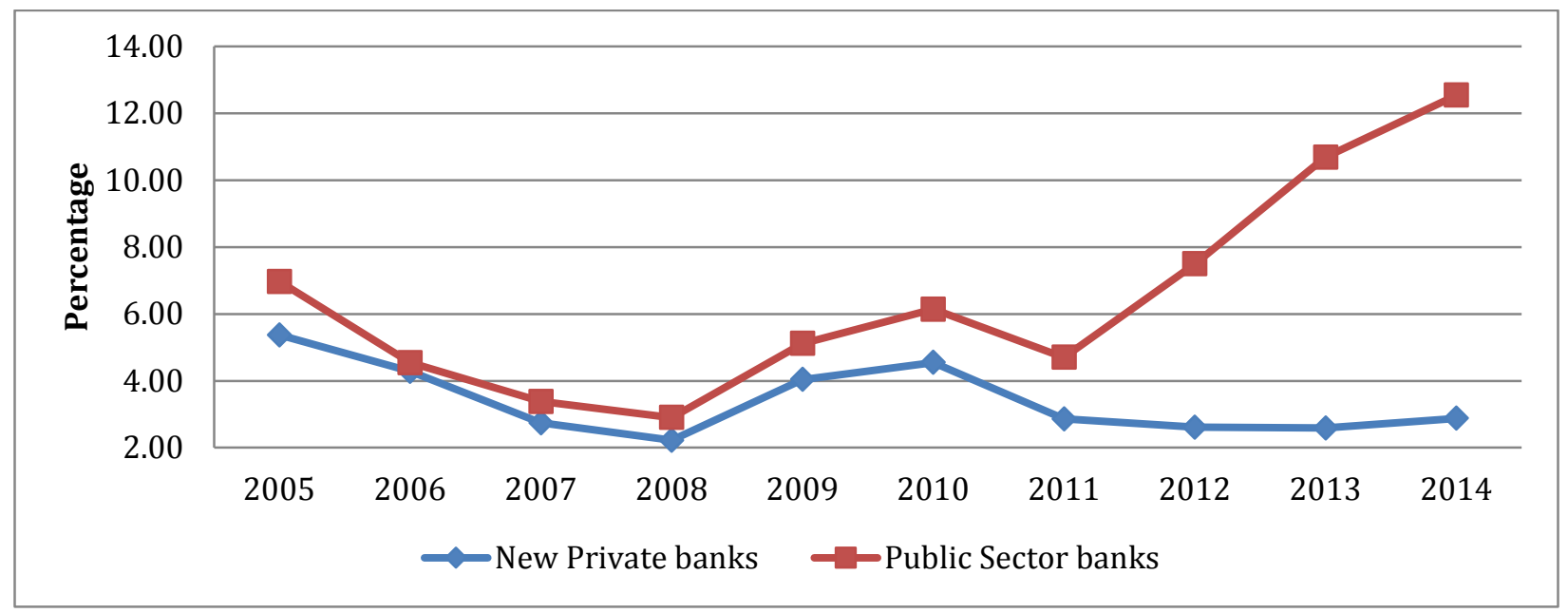




\section{A diagnosis of the problems affecting Indian public sector banks}

\subsection{High asset growth combined with volatile liabilities}

Figure 13 below shows the trend in the assets of public and new private banks. Public sector banks evidently started with huge assets have grown much bigger compared to their private counterparts.

Figure 13: Asset level of public and new private sector banks

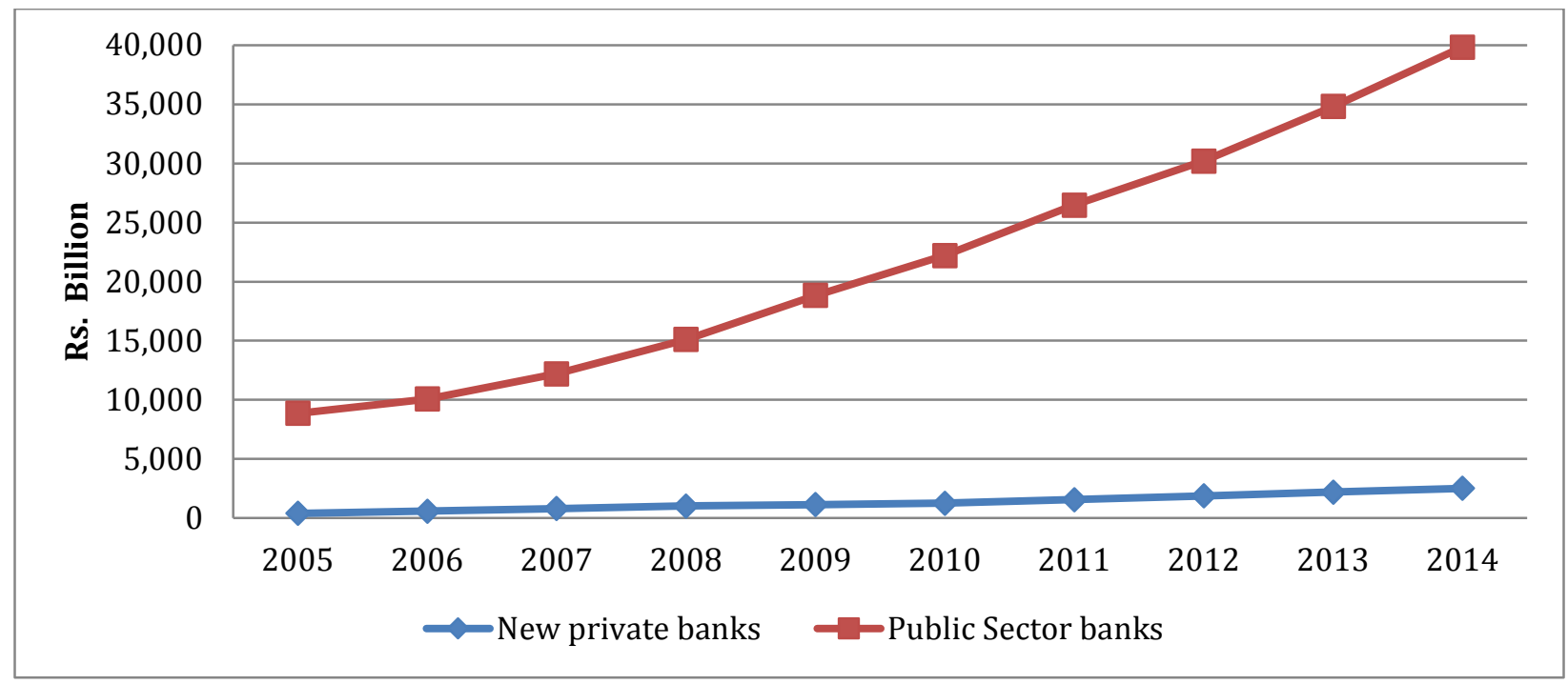

Since it may be unfair to compare the large number of PSBs to few new private banks, we study the growth rate of assets. The growth rate of the assets of new private banks show a marked slump during the crisis while PSBs show only a moderation. In the last three years, we can observe a converging trend with both public and new private banks averaging at around 15\% (Figure 14). Though, both categories of banks may be growing at almost same rate, the sheer size of PSBs is a cause of concern as it poses a systemic threat to the financial system. 
Figure 14: Asset growth of public and new private sector banks

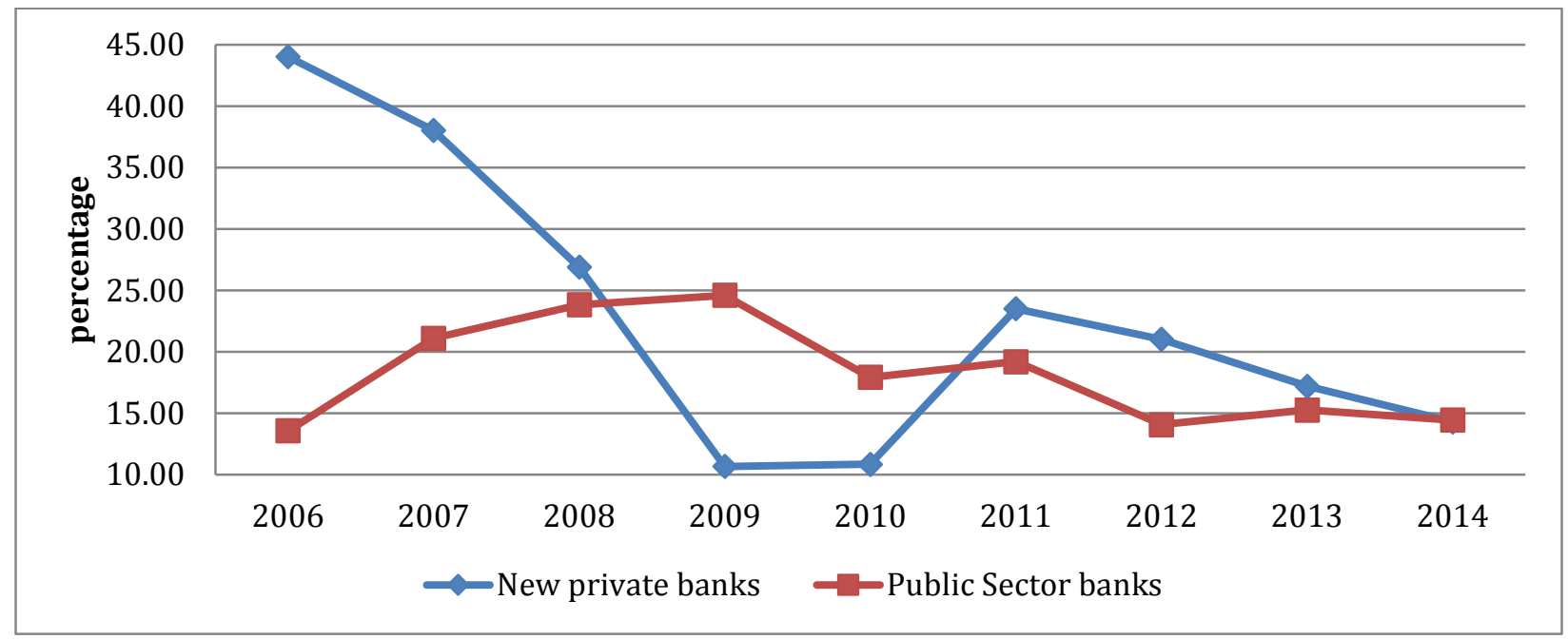

We now examine liquidity risks in the banking system. Leverage ratio, calculated as ratio of total assets of a bank to its equity (capital and reserves) is higher for PSBs (averaging 18.8 per cent) when compared to new private sector banks (averaging 12 per cent) (see Figure 15). This shows that any macroeconomic shock that leads to reduction in value of assets will affect PSBs to a greater extent than the private sector banks.

Figure 15: Total assets to equity (leverage ratio) of public and new private sector banks

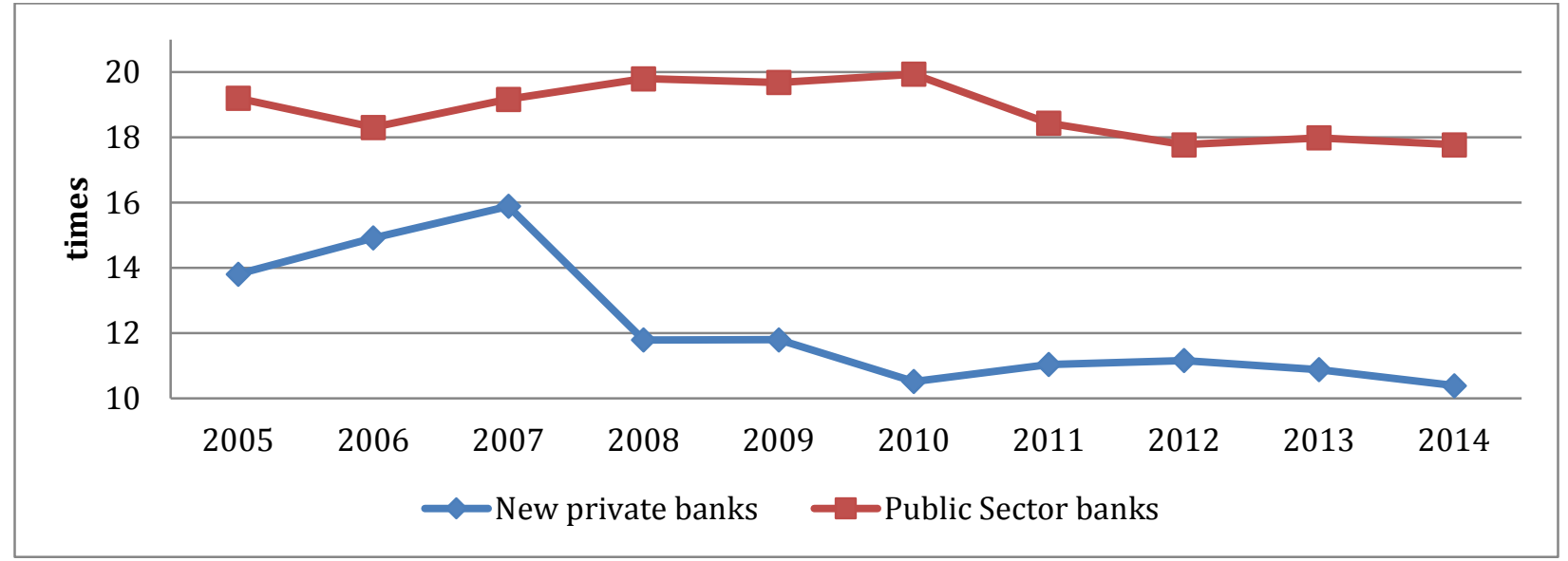

Apart from PSBs being more highly levered, the structure of liabilities of PSBs deserves attention as well. PSBs are funded significantly more with volatile wholesale liabilities when compared to the private sector banks. While private sector banks have reduced their reliance on the volatile wholesale liabilities, PSBs have increased theirs from 30\% in 2008 to approx. 37\% in 2013 (Figure 16). For many of the large nationalized banks, close to 50\% of liabilities is funded with wholesale liabilities. This increases vulnerability of these banks when we take into account the high asset growth in these banks.

Hahm et al. (2013) investigate the role of non-core bank liabilities (components of funding other than retail deposits) in signaling financial vulnerability. They formulate a credit supply model where a bank maximizes profit 
subject to a Value-at-Risk (VAR) constraint. Banks are able to expand lending without violating the constraint when measured risks are low. However, when core deposits do not grow in line with credit supply, banks turn to other sources of funding to support its credit growth, typically from other banks operating as wholesale lenders in the capital market. An important link is established between currency crises and credit crises as the pro-cyclical behavior that fuels credit boom is financed through capital inflows via the banking sector. Empirically, authors find support for this hypothesis. Measures of non-core liabilities, and especially the liabilities to the foreign sector, serve as a good indicator of the vulnerability to a crisis, both of a collapse in the value of the currency as well as a credit crisis where lending rates rise sharply.

This suggests that at least in emerging and developing economies, noncore bank liabilities may be usefully monitored as a complementary measure to the credit to GDP ratio in gauging the stage of financial cycles and the build-up of financial risk. Demirgüç-Kunt and Huizinga (2010) examine the implications of a bank's activity mix (represented by the share of non-interest income in the form of fees, commissions and trading income in total operating income) and funding strategy (deposits vs. other non-deposit short-term funding) for its risk and return. Their analysis reveals a tradeoff that at low levels of non-interest income and non-deposit funding, there may be some risk diversification benefits of increasing these shares, although at higher levels of non-interest income and non-deposit funding shares, further increases result in higher bank risk. This suggests that traditional banks - with a heavy reliance on interest-income generating and deposit funding - are safer than banks with strategies that rely prominently on generating non-interest income or attracting wholesale funding. 
Figure 16: Wholesale liabilities of public and private sector banks

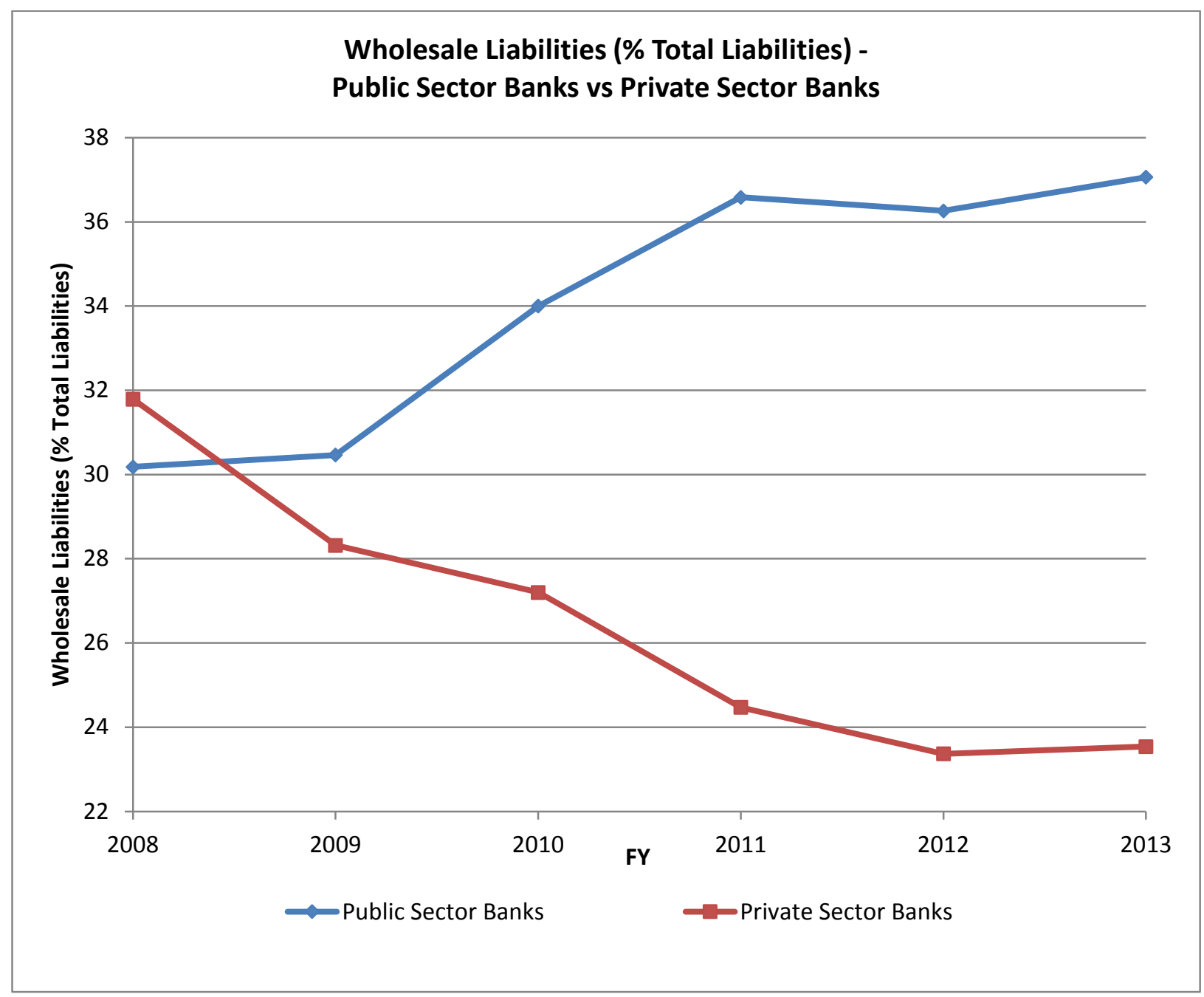

The growth rate of demand deposits and savings deposits also remain high for new private banks compared to PSBs. New private banks after the savings bank account deregulation have started to attract depositors by offering competitive interest rates. After a period of stickiness, this move has triggered the movement of deposits towards new private banks which are in the forefront of gaining of more depositors causing significant dent in the low cost funds of PSBs. The average growth rate of demand deposits of new private banks stood at 21 per cent while that of PSBs stood at 13 per cent during the period considered indicating the expanding share of new private banks. (see Figure 17). 
Figure 17: Growth rate of demand deposits of public and new private sector banks

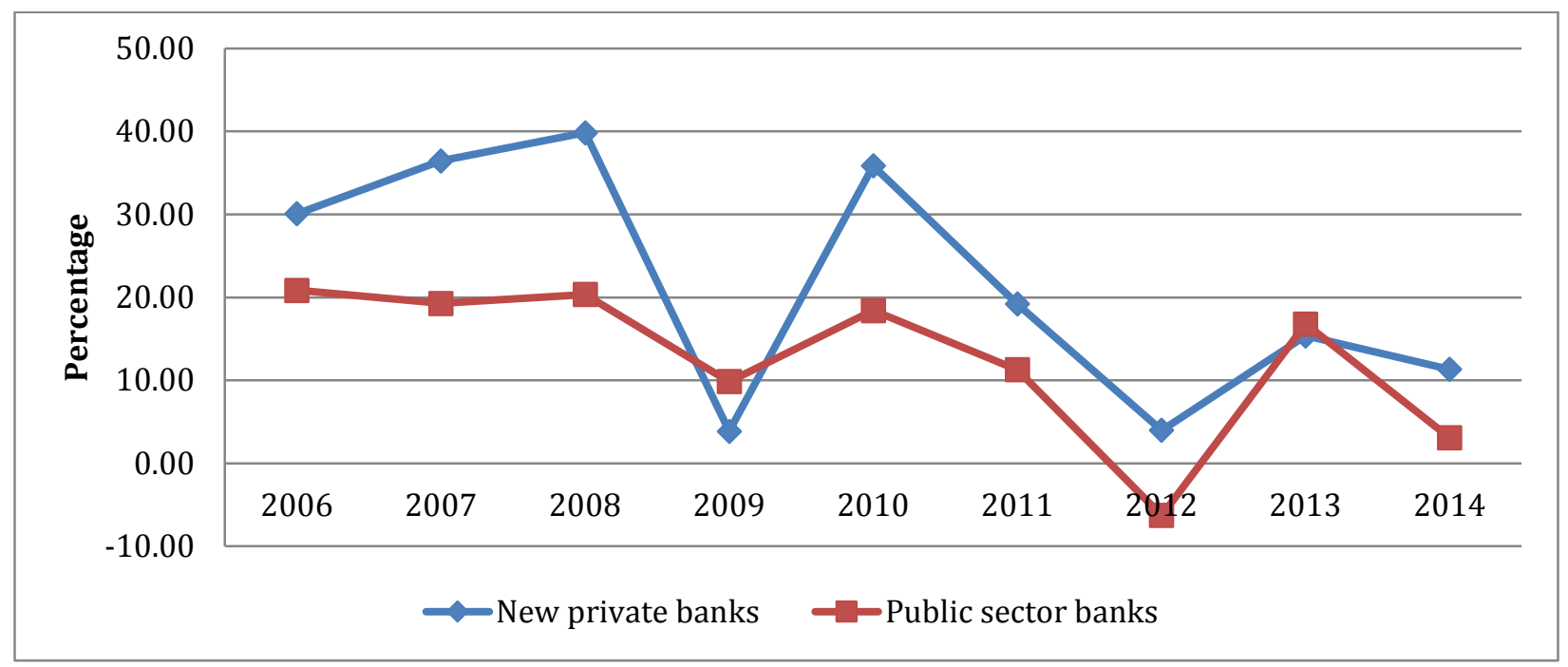

From Figure 18 below showing the growth rate of savings deposits also new private banks average (31 per cent) was much higher than that of PSBs (17 per cent).

Figure 18: Growth rate of savings deposits of public and new private sector banks

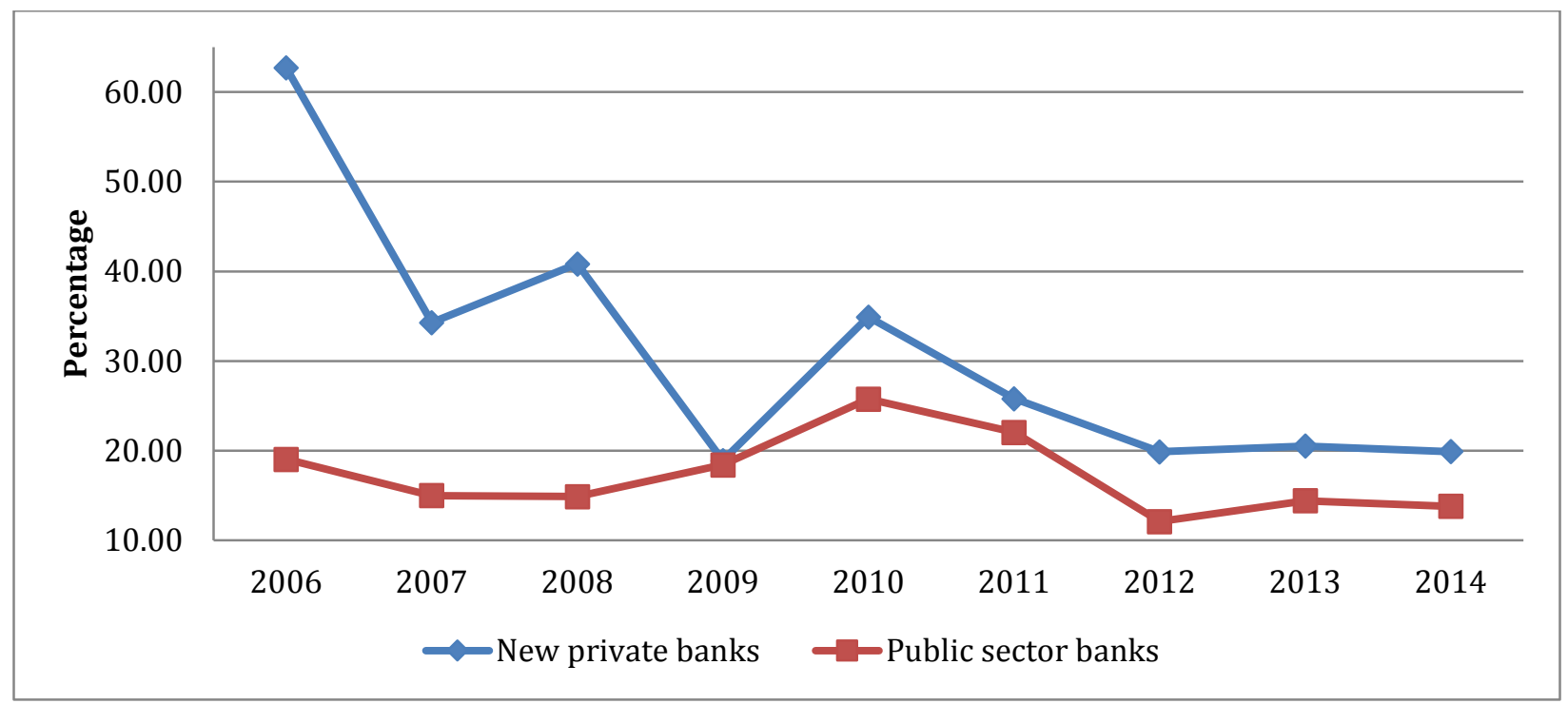

On the other hand, term deposits which are more sticky and prone to transaction lags than savings \& demand deposits have also started to shift towards new private banks as evident from the convergence of their growth rates with that of PSBs. Their averages converged at around 20 per cent considering the slump for new private banks. (see Figure 19). 
Figure 19: Growth rate of term deposits of public and new private sector banks

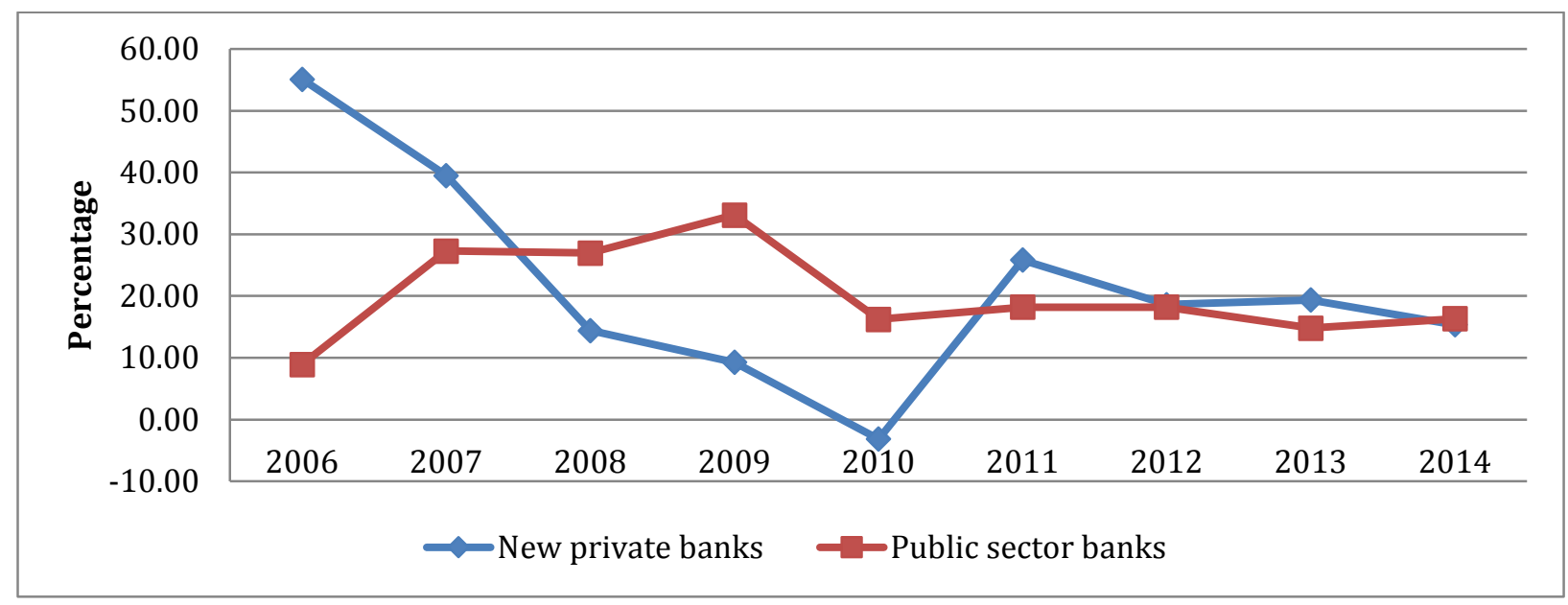

When taken together, the savings and demand deposits, the new private banks clearly outperform the PSBs in gaining both in times of industry moderation and growth. All the above factors can be attributed to the fact that PSBs have gained organizational inertia owing to their implicit sovereign guarantee. This makes them difficult to make adjustments as demanded by market movements ${ }^{3}$. Process oriented improvements, customer oriented decisions and market related adjustments are hard to implement in case of PSBs owing to their lethargic organizational culture and work ethics. Though in short term they may have the privilege of retaining customers owing to their strong market presence but as the economy grows and customer becomes more aware, they may have to be nimble and lean in order to make swift decisions conducive to market movements. (see Figure 20).

Figure 20: Growth rate of CASA deposits of public and new private sector banks

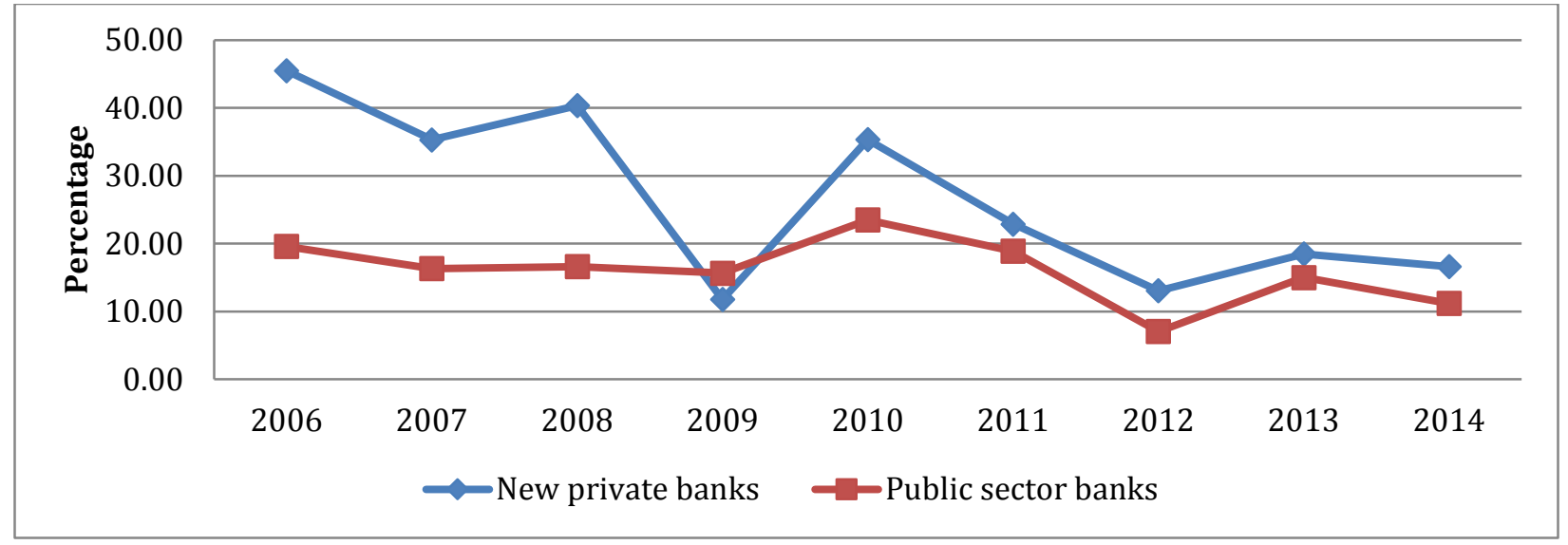

Considering the fact that PSBs have implicit guarantee of the sovereign, it must be able to raise funds in markets abroad where the investors will tend to be more risk averse considering market asymmetry. However, when it

\footnotetext{
${ }^{3}$ http://www.business-standard.com/article/finance/govt-banks-won-t-pay-more-on-savings-a-cs-111110600031_1.html
} 
comes to borrowings raised abroad new private banks though smaller in number have on an average raised more than double of that of PSBs. (see Figure 21).

Figure 21: Borrowings outside India of public and new private sector banks

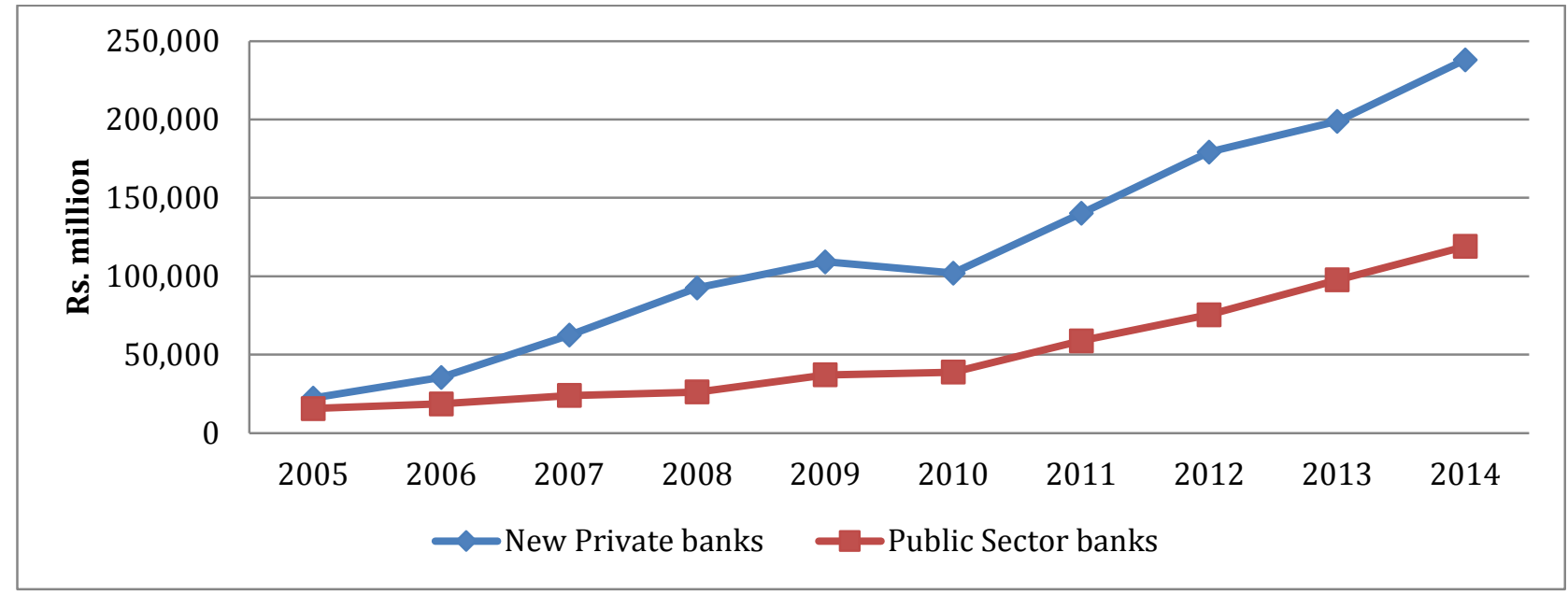

\subsection{Risks due to lower efficiency of operations}

Almost all the accounting measures reveal that PSBs are much less efficient compared to new private banks. Since these information are gathered at the organizational level it is important for us to look at the operational level information also to arrive at a better picture on the performance of PSBs.

We compare the efficiency of these two categories of banks using metrics like business per employee and profit per employee which succinctly captures the process and organizational efficiency. We can observe that the though business per employee has increased for the PSBs, profits per employee has decreased from 2011 (see Figure 22). This indicates that PSBs have exploited the strength of their existing network and have expanded their business via deposits \& loans. However, they have not been translated into profits as evident from a drop in the value. On the other hand, new private banks have been consistently outperformed PSBs when it comes to profit per employee by an average of Rs. 3 lakhs. Also, we need to observe the secular increase in profit per employee in spite of the moderation of business per employee among new private banks (see Figure 23). It indicates that they have an agile organization that efficiently utilizes the human capital by allocating them to profitable business units. 
Figure 22: Business per employee of public and new private sector banks

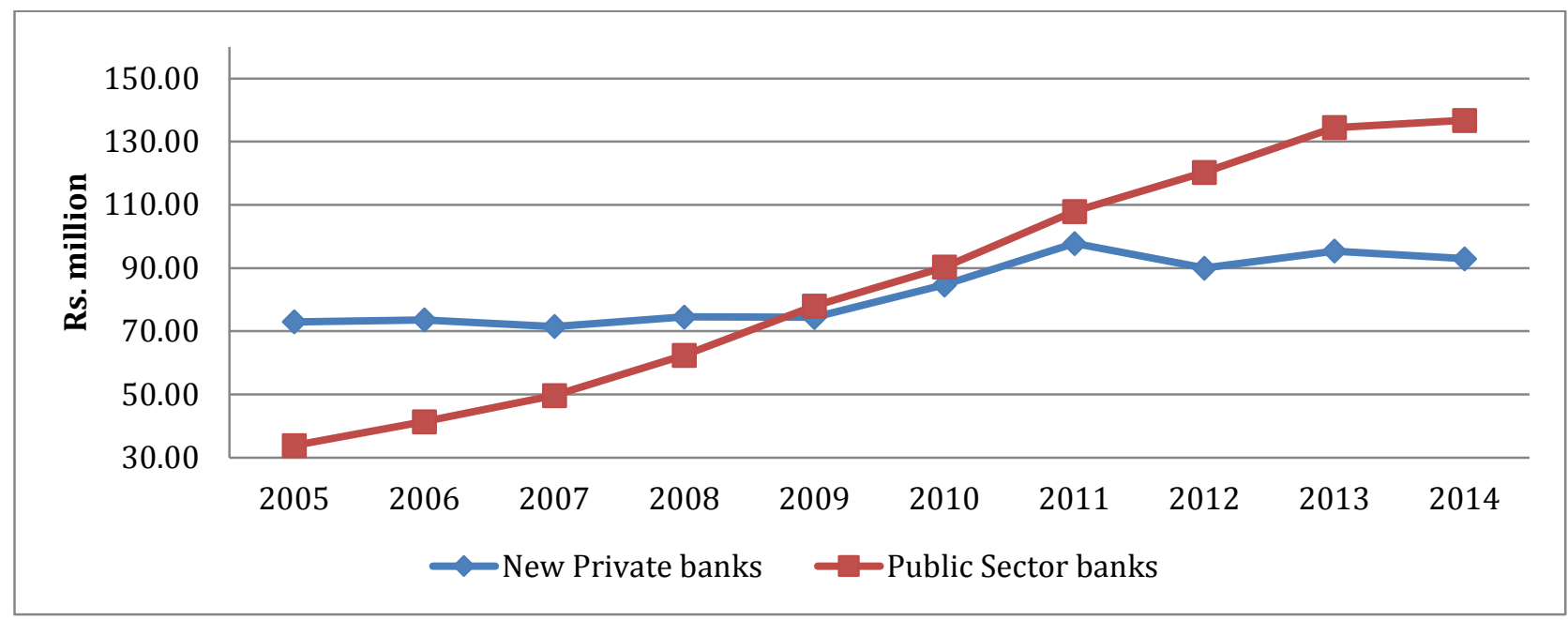

Figure 23: Profit per employee of public and new private sector banks

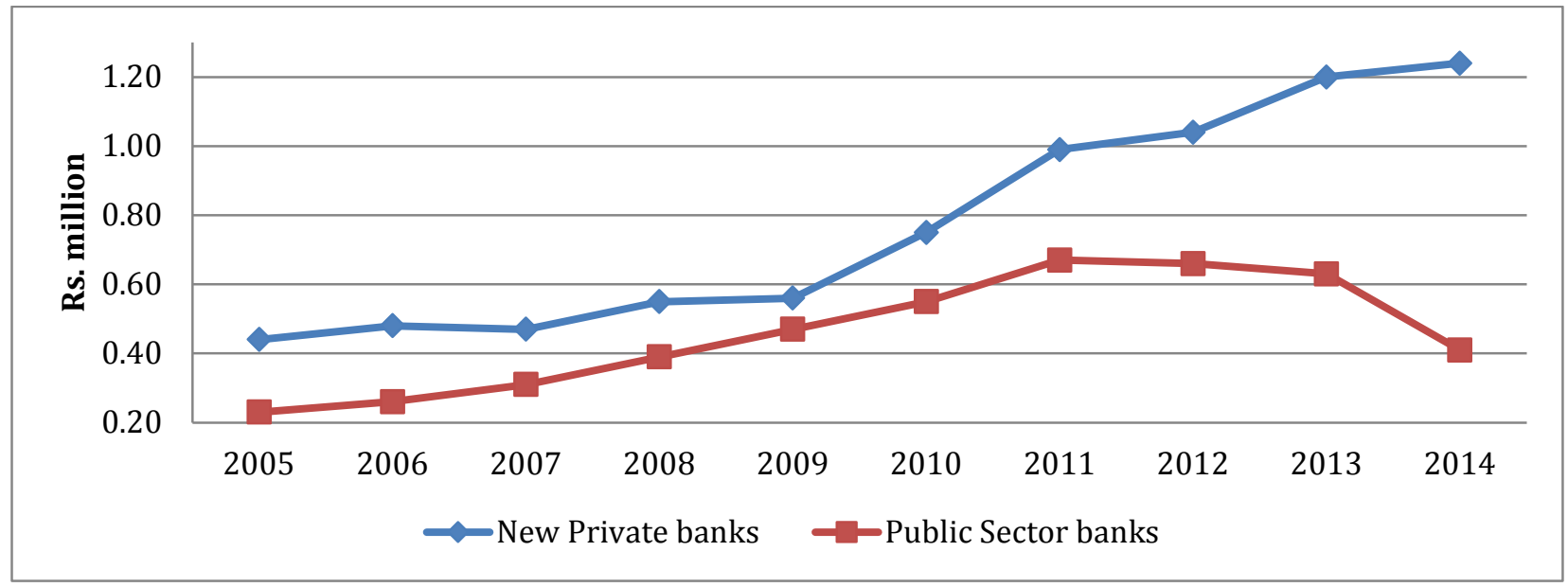

A key source of revenue for banks, fee income, defined as a total of commission, exchange and brokerage income as a proportion of total income indicates how much the bank exploits the existing business network, human resources and economies of scale in its operations. New private banks have consistently surpassed the PSBs where they average about 12 per cent over the past 10 years while PSBs average about 5 per cent (see Figure 24). This shows a remarkably huge variation in exploiting the strengths of the banking network to expand the business. 
Figure 24: Ratio of Fee income to Total Income of public and new private sector banks

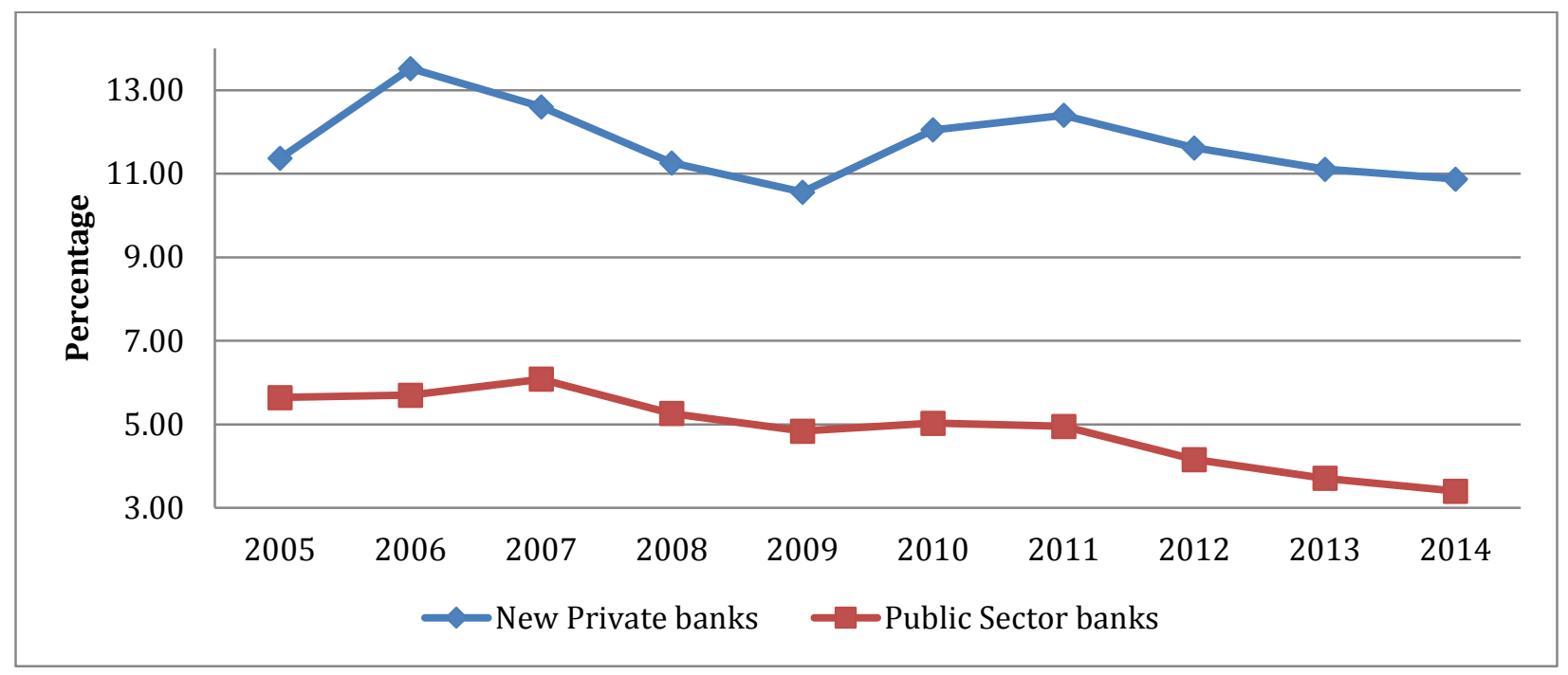

Another measure to measure the operational efficiency could be to compare cost incurred by the bank for staffing \& other expenses to the income from its core operations, i.e., interest income. This ratio is defined as the ratio of net non-interest expenses incurred to the interest income of the bank. In this comparison, we find that the new private banks over the years have spent more to establish the network and over the years they have started to exploit its strengths indicated by a declining trend. On the other hand, even though PSBs already had a well established network their value also converges with that of new private banks over the past 4 years. (see Figure 25). 
Figure 25: Ratio of net non-interest expenses incurred to the interest income

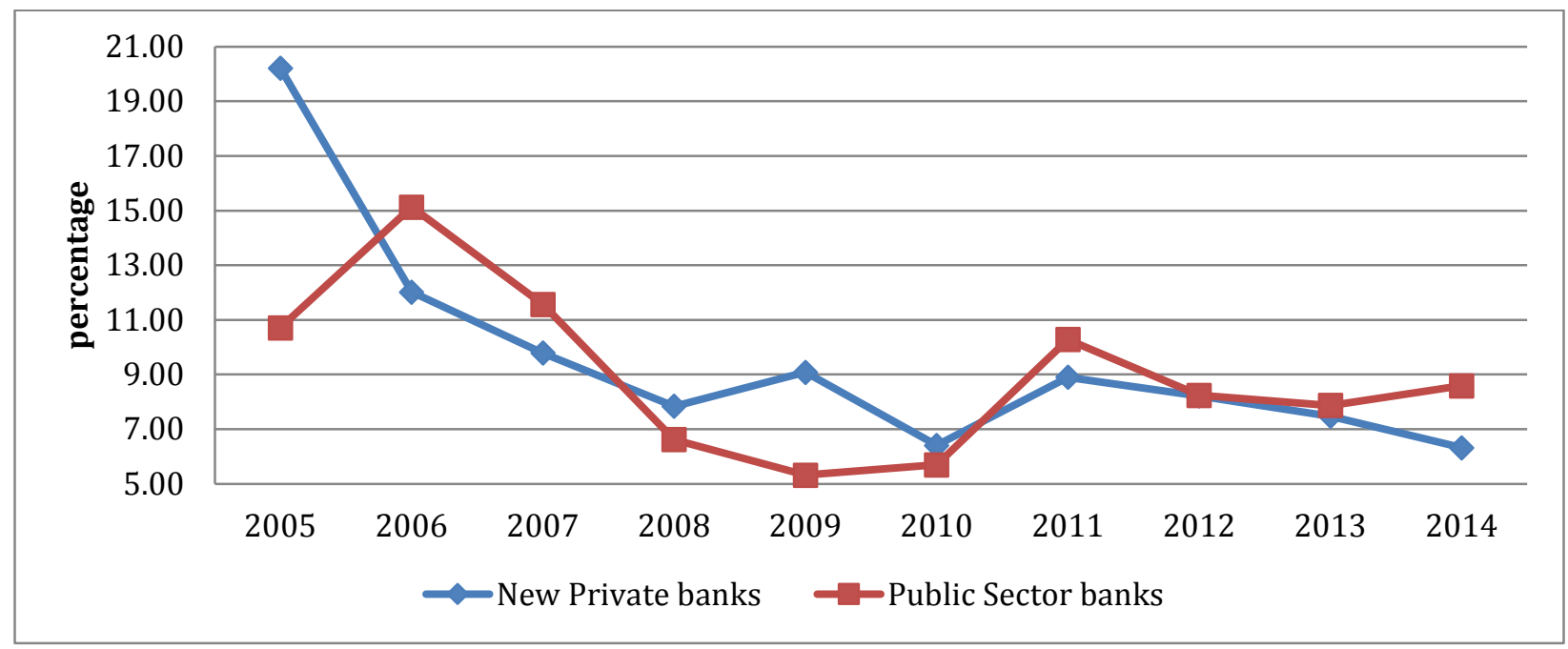

Another operational function of banks can be observed in the transactions that they perform. The following Figure 26 shows the growth rate of RTGS (Real Time Gross Settlement system) transactions in public and new private banks. We can observe that the growth rate of new private banks has been consistently above that of public sector banks indicating they are becoming important nodes in the banking network in payment and settlement systems.

Figure 26: Growth rate of RTGS transactions of public and new private banks (as on March of each year)

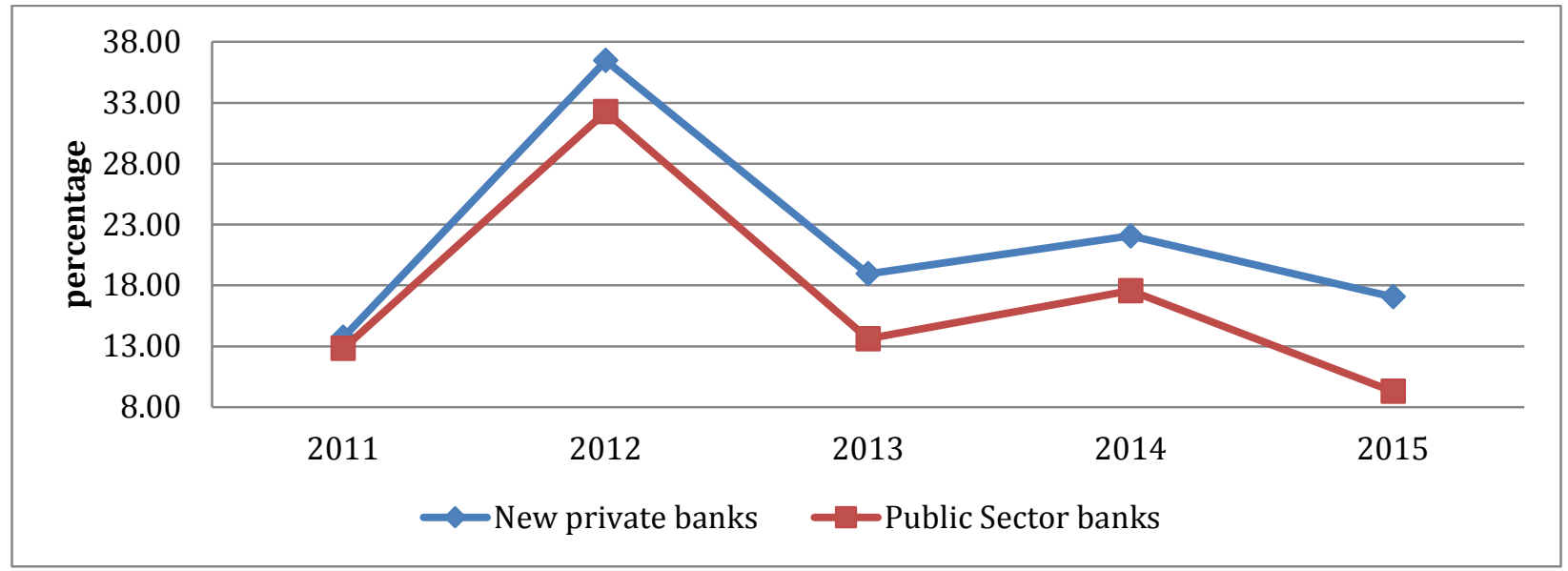

The staffing cost could also indicate a great deal about the labor efficiency of the organization. In 
Figure 27, the ratio of wage bills (payments and provisions to employees) to total income for PSBs indicate a comovement with that of new private banks as it consistently maintains lower staff payment ratio compared to PSBs indicating better resource management.

Figure 27: Ratio of wage bills to Total Income of public and new private banks

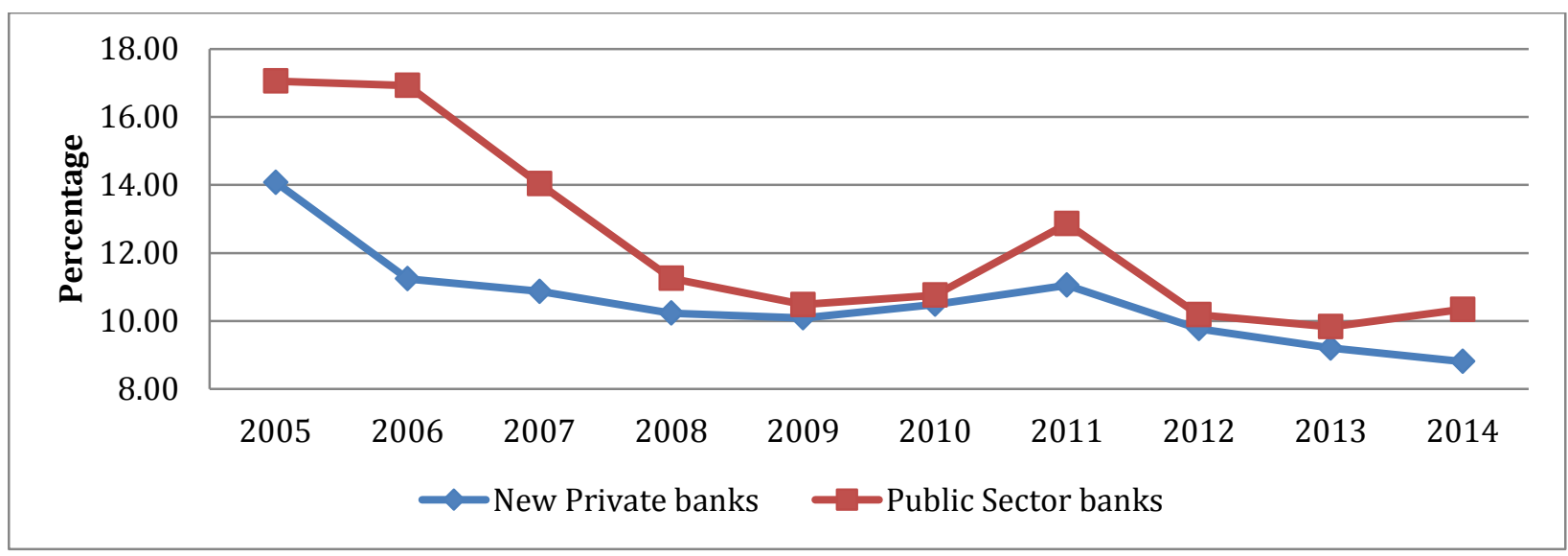

\section{3. $\quad$ Risks due to human capital}

In the case of banks, the role of effective human resources becomes critical considering the knowledge and relationship based nature of the banking business. Credit decisions, asset-liability management, treasury operations, customer relationship and various other functions in banking are driven by effective human resources who need to take professional decisions on the basis of intelligent judgement and proficiency. Hence, it becomes important to analyze the risks posed by human capital among PSBs and assess their impact on the industry.

As highlighted by McKinsey (2013) , PSBs are facing significant challenges with respect to their human capital, over 60 to 90 per cent of the GMs/DGMs (General Managers/ Deputy General Managers) who form the core of the middle management in PSBs are set to retire by 2016-17. The shortfall for talent for PSBs is driven by high average age leading to high retirements at the senior management levels. The average age of employees across levels was 41 years for PSBs in 2012-13 (down from 46 years in 2010-11). The same for private sector banks was 33 years in 2012-13 (again down from 34 years in 2010-11).

In PSBs, more than three-fourths of the current population for levels AGM (Assistant General Manager) and above is expected to retire by 2020. Initial estimates for the next year indicates a 10 to 15 per cent shortfall for PSBs at senior levels (chief manager and above) for a "zero growth scenario". This shortfall is the difference of people exiting a particular level through attrition and retirements and entering through recruitment, while accounting for promotions. The survey conducted by McKinsey (2013) reveals that the PSBs lag behind their private sector counterparts on almost all dimensions of performance management. This leads to skewed priorities which are not aligned with the organizational goals producing distortionary results. Also, the employees of PSBs are governed by dual guidelines and regulations. They have to adhere to model code of conduct as framed by the bank board 
at the same time they can be investigated by Central Vigilance Commissioner as PSBs come under Ministry of Finance regulated by Public sector staff regulations. Such dual restrictions affect the decision making skills of the management at the same time lowering their morale. Clearly, this kind of a situation is not applicable to private sector banks as their employees have to adhere only to their corporate guidelines. This shortfall in human capital will be even greater if the PSBs have to record a more realistic growth in their business. This situation will further worsen if the government and the Reserve bank of India do not take steps to address (i) the substantial gap in the evaluation process of PSBs, and (ii) align incentives to reward performance.

The survey conducted by McKinsey (2013) reveals that the PSBs lag behind their private sector counterparts on almost all dimensions of performance management. This leads to skewed priorities which are not aligned with the organizational goals producing distortionary results. Also, the employees of PSBs are governned by dual guidelines and regulations. They have to adhere to model code of conduct as framed by the bank board at the same time they can be investigated by Central Vigilance Commissioner as PSBs come under Ministry of Finance regulated by Public sector staff regulations. Such dual restrictions affect the decision making skills of the management at the same time lowering their morale. Clearly, this kind of a situation is not applicable to private sector banks as their employees have to adhere only to their corporate guidelines.

\subsection{Risks due to disruptive technologies}

Banking as a process has been revolutionalized by technology like any other industry, bringing a whole new perspective in credit management, liquidity management, treasury operations, payment \& settlement systems and customer service. Such technologies that are improving the scale and efficiency of operations can be incremental (process improving) or disruptive (drastically leaping to next generation service) depending on their scale of impact on the industry. From the figure below, we can observe that the young and affluent population prefers to use the Internet and mobile medium for banking services forcing to invest more on these medium of service delivery.

Such a technological change could be significantly more disruptive for PSBs than for their private sector counterparts mainly due to their huge size. Banking customers are increasingly using multiple channels for their day to day transactions considering their cost and speed of service. Usage of internet and mobile banking channels have grown dramatically by $110 \%$ and 100\% respectively from 2011 to 2013 (McKinsey, 2013). Banks must innovate on their existing distribution models to ensure that they reach customers through digital channels, which can generate significant gains in productivity and cost-efficiency. Also, there is a significant shift in channel preferences among younger and wealthier segment of customers of Asian banks, specifically towards non-branch channels. As a result, customers in future are likely to demand even more digital services from banks. In India, the number of potential digital banking consumers could rise to approximately 450 million in 2020 from 100 million in 2012. 
As McKinsey (2013) demonstrates, the advent of digital banking will create significant value for the front-runners in adopting digital technology while at the same time destroying significant value for the laggards. In fact, the impact on profits or losses could be anywhere between $30 \%$ to $50 \%$ depending on the bank's starting point and how it responds to these digital trends. PSBs in India are less well-positioned to take advantage of these disruptive innovations when compared to their private sector counterparts. From Figure 35, most private banks (approx. two-thirds), recognize this progressive shift in the nature of banking and are focused on moving to the next level while only a third of the PSBs are investing in moving to this next level.

To better understand, we can observe the number and value of mobile transactions undertaken by these two bank categories. We can observe from Figure 36 that number of mobile transactions that the new private banks have been quick to catch up with PSBs even though they are much smaller in number. Starting from the same position in 2010, new private banks have equaled with that of PSBs in 5 years in terms of the volume of mobile transactions. Also, on the other hand, new private banks have surpassed the PSBs in terms of value of mobile transactions (see Figure 37). The current value of transactions with new private banks equal more than 2.5 times of that of all the PSBs put together, showing the effective adoption of new mobile technology services by private sector banks.

Figure 28: Volume of mobile transactions of public and new private sector banks

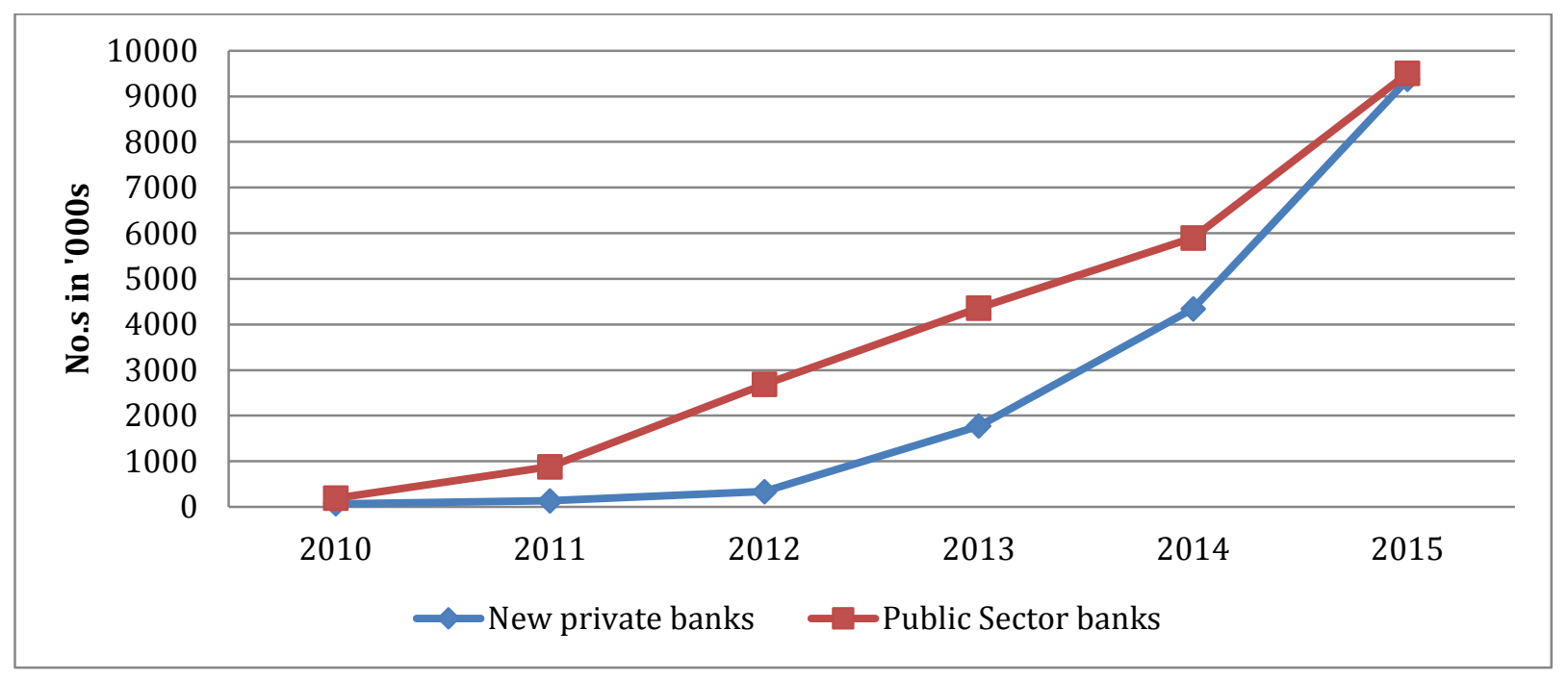


Figure 29: Value of mobile transactions of public and new private sector banks

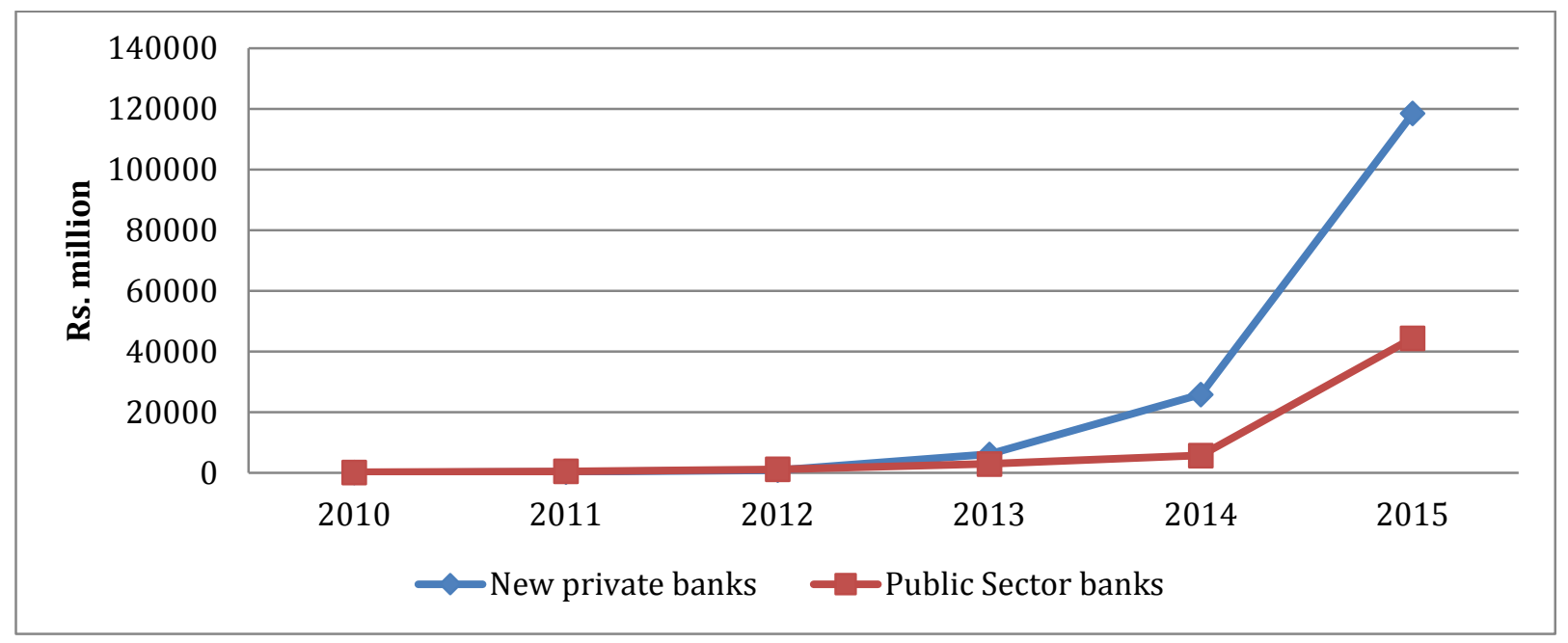

\section{Conclusions and Policy Implications}

Our analysis of the Indian banking sector has highlighted the precarious condition of public sector banks. Given the ills affecting the public sector banks, the onus of remedying this situation through radical reform lies primarily with the Government. In the absence of such reform, or if reform is piecemeal and non-substantive, it is unlikely that there will be material improvement in their performance. This could impede the Government's objective of fiscal consolidation if the Government has to recapitalize the public sector banks. On the other hand, if the Government decides not to spend taxpayer money in such recapitalization, then public sector banks would have to significantly shrink their balance sheets in order to maintain adequate capital. Given the critical importance of public sector banks in the financial intermediation needs of the Indian economy, such shrinkage would have significant dampening effects on economic growth. Either way, the cost of inadequate reform of public sector banks will be steep. We suggest the following steps for correcting the state of public sector banks.

First, some of the public sector banks that have most gearing should be recapitalized now and their debts reduced, as they still have reasonable market values of equity. This could be achieved for instance through deep-discount rights issues as a number of academics has suggested. This will put the burden of further losses on their shareholders rather than on taxpayers in due course. It is also likely to improve their incentives to restructure troubled assets promptly.

Second, many of the problems relating to the efficiency of public sector banks, the quality of their human capital as well as their ability to adapt a rapidly changing technological landscape arise in large measure from the manner in which the public sector banks are governed. As has been highlighted by the P J Nayak committee, the boards of most of these banks lack the necessary expertise as well as the required sense of purpose to steer the banks through their present difficult position. The boards are disempowered, and the selection process for directors is 
increasingly compromised. Board governance as well as overall governance is consequently weak. Governance difficulties in public sector banks also arise from several externally imposed constraints. These include dual regulation, by the Finance Ministry in addition to RBI; board constitution, wherein it is difficult to categorize any director as independent; significant and widening compensation differences with private sector banks, leading to the erosion of specialist skills. In order to improve governance of public sector banks, the Government must distance itself from several bank governance functions that it presently discharges. For this purpose, the Bank Nationalization Acts of 1970 and 1980, together with the SBI Act and the SBI (Subsidiary Banks) Act must be repealed. All banks be incorporated as regular corporations under the Companies Act and must be mandated to satisfy the corporate governance norms prescribed by the Securities Exchange Board of India. The process of board appointments, including appointments of whole-time directors, needs to be professionalized.

Third, public sector banks need to be slowly weaned off their funding advantage coming from government guarantees. In the short run, this could be achieved by requiring them to pay a deposit insurance premium that compensates for the guarantee they cash in on in stress times. They could also be subjected to larger capital buffers given their funding reliance on the state rather than the market.

Finally, over the long run, some of the public sector banks can be privatized or their assets reallocated. Some of them could be acquired by the relatively well-capitalized private sector firms; the ones with worst asset quality could be wound down; and, greater entry of smaller and newer banks can be enabled to yet maintain healthy levels of competition. 


\section{References}

Acharya, V. V., Engle, R. and Richardson, M. P., 2012, "Capital Shortfall: A New Approach to Ranking and Regulating Systemic Risks", American Economic Review Papers and Proceedings, 102(3), 59-64.

Acharya, V. V., Engle, R. and Pierret, D., 2014, "Testing Macro-prudential Stress Tests: The Risk of Regulatory Risk Weights", Journal of Monetary Economics, 65, 36-53.

Acharya, V. V., Pedersen, L. H., Philippon, T, and Richardson, M. P., 2010a, "Measuring Systemic Risk", in Regulating Wall Street: The Dodd-Frank Act and the New Architecture of Global Finance, Acharya, V. V., Cooley, T., Richardson, M, and Walter, I. (Eds), John Wiley \& Sons.

Acharya, V. V., Pedersen, L. H., Philippon, T, and Richardson, M. P., 2010b, "Taxing Systemic Risk", in Regulating Wall Street: The Dodd-Frank Act and the New Architecture of Global Finance, Acharya, V. V., Cooley, T., Richardson, M, and Walter, I. (Eds), John Wiley \& Sons.

Acharya, V. V., Pedersen, L., Philippon, T., and Richardson, M., 2010c, "Measuring Systemic Risk", Technical report, Department of Finance, NYU Stern School of Business.

Brownlees, C. and Engle, R., 2011, "Volatility, Correlation and Tails for Systemic Risk Measurement", Working Paper, New York University.

Calomiris, C. and R. Herring, 2013, "How to Design a Contingent Convertible Debt Requirement That Helps Solve Our Too-Big-To-Fail Problem", Journal of Applied Corporate Finance, 25(2), 66-89.

Demirgüç-Kunt and Harry Huizinga, 2010, "Bank Activity and Funding Strategies: The Impact on Risk and Returns", Journal of Financial Economics.

Engle, R., 2011, “Dynamic Conditional Beta”, Volatility Institute manuscript, NYU.

Hahm, Shin and Hyun-Song Shin, 2013, "Non-core bank liabilities and financial vulnerability", Journal of Money, Credit and Banking.

McKinsey, 2013, McKinsey Bank Benchmarking survey, McKinsey \& Co. 


\section{Appendix: SRISK - a measure of financial sector health}

Acharya (2009) and Acharya, Pedersen, Philippon and Richardson (2010a, b, c) argue that systemic risk should not be described in terms of a financial firm's failure per se but in the context of a firm's overall contribution to system-wide failure. The intuition is that when only an individual financial firm gets distressed, i.e., its equity capital becomes low relative to its promised debt- or debt-like liabilities, there are minimal economic consequences because healthier financial firms can fill in for the failed firm's void in intermediation services. When capital is low in the aggregate, however, it is not possible for other financial firms to step into the breach. This breakdown in aggregate financial intermediation is the reason there are severe consequences for the broader economy such as credit crunch and fire sales of assets.

Acharya, Engle and Richardson (2012) implement this intuition by proposing a measure of systemic risk contribution of a financial firm, called SRISK and measured as the expected capital shortfall of a firm in a crisis. In particular, SRISK, of firm $i$ at time $t$ is defined as the capital that the firm is expected to need (conditional on available information up to time $t-1$ ) to operate "normally", i.e., not face a "run" of its creditors, if we have another financial crisis. Symbolically it can be defined as

$$
\operatorname{SRISK}_{i, t}=E_{t-1}\left(\text { Capital Shortfall }_{i} \mid \text { Crisis }\right)
$$

Brownlees and Engle (2011) (see also Engle, 2011) provides the econometrics of estimating SRISK by modeling the bivariate daily time series model of equity returns on firm $i$ and on a broad market index using publicly available data. The results of this analysis are updated weekly and posted at New York University Stern School of Business Volatility Institute (NYU Stern VLAB) website http://vlab.stern.nyu.edu/welcome/risk. Results are posted both for approximately 100 US financial firms and for 1200 global financial firms.

To calculate SRISK, we first need to evaluate the losses that an equity holder would face if there is a future crisis. To do this, volatilities and correlations of individual financial firm's equity return and the global market-wide return are allowed to change over time and simulated for six months into the future many times. Whenever the broad index falls by $40 \%$ over the next six months, a rather pessimistic scenario that captures the kind of market collapse witnessed during the Great Depression in 1930's and the Great Recession in 2007-09, this is viewed as a crisis. For these scenarios, the expected loss of equity value of firm $i$ is called the Long Run Marginal Expected Shortfall or LRMES. This is just the average of the fractional returns of the firm's equity in the crisis scenarios. ${ }^{4}$

${ }^{4}$ In versions of the model where the simulation is not yet implemented on VLAB, LRMES is approximated as 1-exp $\left(-18^{*} M E S\right)$ where MES is the one day loss expected if market returns are less than $-2 \%$. MES in 
The capital shortfall can be directly calculated by recognizing that the book value of debt will be relatively unchanged during this six-month period while equity values fall by LRMES. Assume a prudential capital ratio is considered to be $k$ which we take as $8 \%$ (and $5.5 \%$ for Europe to adjust for the differences between the European IFRS and US GAAP accounting standards in the treatment of netting of derivatives). Then we can define SRISK, of firm $i$ at time $t$ as:

$$
\begin{aligned}
\text { SRISK }_{i, t} & =E_{t-1}((k(\text { Debt }+ \text { Equity })-\text { Equity }) \mid \text { Crisis }) \\
& =k\left(\text { Debt }_{i, t}\right)-(1-k)\left(1-\text { LRMES }_{i, t}\right) \text { Equity }_{i, t}
\end{aligned}
$$

where Equity $_{i, t}$ is the market value of equity today, $D e b t_{i, t}$ is the notional value of non-equity liabilities today, and $L R M E S_{i, t}$ is the long-run marginal expected shortfall of equity return estimated using available information today. This measure of the expected capital shortfall captures many of the characteristics considered important for systemic risk such as size and leverage. These characteristics tend to increase a firm's capital shortfall when there are widespread losses in the financial sector. But a firm's expected capital shortfall also provides an important addition, most notably the co-movement of the financial firm's assets with the aggregate market in a crisis. ${ }^{5}$

Before we employ estimates of SRISK to provide a comparative analysis of the global financial sector health, few points are in order.

First, SRISK can be considered as the capital shortfall estimate for a financial firm based on a market-data based "stress test". Stress tests have now become a standard device used by regulators to determine the capital that an institution will need to raise if there is a macroeconomic shock. ${ }^{6}$

related to other standard measures of financial risk also reported on VLAB, such as Corr, which is the correlation between a stock's return and the aggregate market, and $V O L$, which is the annualized volatility of a stock's return. Note that VLAB also reports the Beta of a stock which is the \%change in a stock's price for a \%change in the aggregate market price; however, Beta is symmetric and does not give the \%change in a stock's price for a downward movement in aggregate market.

${ }^{5}$ In this sense, SRISK is based on a notion of systemic risk in which a "tsunami"-type shock hits the global economy rather than a "contagion"-type shock in which an individual financial firm's interconnectedness causes losses elsewhere in the financial system. The latter would, however, also be statistically picked up in a co-movement of a financial firm's assets with the aggregate market providing that the contagion does have market-wide impact.

${ }^{6}$ Acharya, Engle and Pierret (2014) summarize the adoption of stress tests by regulators in the United States and the Europe: "An annual supervisory stress test of the financial sector in the United States has become a requirement with the implementation of Dodd-Frank Wall Street Reform and Consumer Protection Act (Pub.L. 111-203, H.R. 4173) of 2010. Macroprudential stress tests have also been used by U.S. and European regulators to restore market confidence in financial sectors during an economic crisis. As a response to the recent financial crisis, the 2009 U.S. stress test led to a substantial recapitalization of the financial sector in the U.S. In Europe, the 2011 stress test also served as a crisis management tool 
Regulatory stress tests employ book value of equity capital, estimate losses using models that map macroeconomic stress into asset losses, and require book values of capital to be sufficiently high based on regulatory risk-weighted assets. ${ }^{7}$ In contrast to regulatory stress tests, SRISK is based on the market value of equity capital, estimates losses using market-data based estimate of downside risk of market equity or its vulnerability to a crisis, and requires market values of capital to be sufficiently high relative to quasi-market value of assets (measured as market value of equity plus the book value of non-equity liabilities). As a result, while the regulatory notion of leverage corresponds to risk-weighted assets divided by a measure of book value of equity of a financial firm, the notion of leverage captured in SRISK is quasi-market leverage, which is quasi-market value of assets divided by the market value of equity.

Second, as argued by Calomiris and Herring (2013) (see their Figures 3 and 4, in particular), an important advantage of using the market value of equity and its exposure to a crisis or aggregate downturn is that market-based signals of financial sector distress have been found to be much better as early-warning signals than regulatory measures of financial sector risk (risk-weighted assets to total assets) and book values of equity.

Third, and related to the second point, regulatory risk weights for asset classes are inherently static in nature whereas the true economic risk of asset classes fluctuates over time. Indeed, combined with shifts in financial leverage, the "change that risk will change" can be considered an essential cause of financial crises. Acharya, Engle and Pierret (2014) demonstrate that market-based risk assessments of financial firm balance-sheets, in particular, using the SRISK measure and its components, captured better the actual stress of financial firms in Europe during 2011, relative to the regulatory risk assessments, which relied on static risk weights, notably zero risk-weights for risky sovereign bonds of countries in the southern European periphery.

Fourth, since it is based on market data, one limitation of SRISK is that it can be computed only for financial firms whose equity is publicly traded. In other words, it cannot be computed readily for privately held financial firms. Hence, all assessment of global financial sector health and comparative analysis across countries that follows is subject to this important caveat.

during the European sovereign debt crisis. The European exercise lacked credibility in this role, however, due largely to the absence of a clear recapitalization plan for banks failing the stress test."

7 Again quoting Acharya, Engle and Pierret (2014): "The current approach to assessing capital requirements is strongly dependent on the regulatory capital ratios defined under Basel Accords. The capital ratio of a bank is usually defined as the ratio of a measure of its equity to a measure of its assets. A regulatory capital ratio usually employs book value of equity and risk-weighted assets, where individual asset holdings are multiplied by corresponding regulatory 'risk weights'. The regulatory capital ratios in stress tests help regulators determine which banks fail the test under the stress scenario and what supervisory or recapitalization actions should be undertaken to address this failure." 
Finally, given the simple formulaic structure for SRISK, we can also understand changes in SRISK over time as coming from changes in its components, the book value of non-equity liabilities, the market value of equity, and the market value of equity times the LRMES, as follows:

$$
\begin{aligned}
& \Delta \text { SRISK }_{i}=\text { SRISK }_{i, t}-\text { SRISK }_{i, t-1} \\
& =\Delta \text { Debt }_{i}+\Delta \text { Equity }_{i}+\Delta \text { Risk }_{i}, \text { where } \\
& \Delta \operatorname{Debt}_{i}=k\left(\operatorname{Debt}_{i, t}-\operatorname{Debt}_{i, t-1}\right) \text {, } \\
& \Delta \text { Equity }_{i}=-(1-k)\left(\text { Equity }_{i, t}-\text { Equity }_{i, t-1}\right) \text {, and } \\
& \Delta \text { Risk }_{i}=(1-k)\left(\text { LRMES }_{i, t} \text { Equity }_{i, t}-\text { LRMES }_{i, t-1} \text { Equity }_{i, t-1}\right)
\end{aligned}
$$

where the changes in Debt, Equity and Risk are measured over the period from $t-1$ to $t$, and together with the appropriate weights from the SRISK formula in (2), these changes combine to explain the change in SRISK over the period from $t-1$ to $t$.

This decomposition highlights that increases in non-equity liabilities and expected losses in a crisis increase SRISK over time whereas increases in market value of equity decrease SRISK over time. 